$\begin{array}{ll}\text { Research Square } & \begin{array}{l}\text { Preprints are preliminary reports that have not undergone peer review. } \\ \text { They should not be considered conclusive, used to inform clinical practice, } \\ \text { or referenced by the media as validated information. }\end{array}\end{array}$

\title{
A Study of The Relationship Between Bioclimatic Comfort Zones And Land Use: The Case of Sivas Province (Turkey)
}

Can Bülent Karakuş

Sivas Cumhuriyet University

Demet Demiroglu ( $\sim$ ddemiroglu@kilis.edu.tr)

Kilis 7 Aralik University: Kilis 7 Aralik Universitesi https://orcid.org/0000-0002-3934-5319

\section{Research Article}

Keywords: Physiological Equivalent Temperature, Thermo Hygrometric Index, CORINE, bioclimatic comfort zone

Posted Date: November 10th, 2021

DOI: https://doi.org/10.21203/rs.3.rs-1035870/v1

License: @ (i) This work is licensed under a Creative Commons Attribution 4.0 International License. Read Full License 


\section{Abstract}

The aim of this study is to reveal the relationship between bioclimatic comfort zones and land use in Sivas province. In this context, the relationship between the climatic data of 1990 and 2018 and the land use data of Sivas province belonging to the same years was evaluated as seasonal and annual periods. The bioclimatic comfort zones in the study area were determined depending on environmental climatic parameters (ECP) [temperature ( $T$ ), relative humidity (RH) and wind speed (WS)] and bioclimatic indices [Physiological Equivalent Temperature (PET), Thermo Hygrometric Index (THI), and Universal Thermal Climate Index (UTCI)]. The values of the environmental climate parameters of Sivas province for the relevant years were obtained from 9 meteorological stations, the height of which varies between $1121 \mathrm{~m}$ and $1528 \mathrm{~m}$. With the help of the Geographical Information System (GIS), the spatial distribution of the bioclimatic comfort zones determined depending on the environmental climate parameters and bioclimatic indices were created. Land use maps of the study area for reference years were obtained by using CORINE land cover data. The relationship between bioclimatic comfort zones and land use was also determined with the help of GIS. According to the results of this study; It was determined that the land use type in which the bioclimatically comfortable areas overlap in Sivas province differs according to the used parameter/indexes, years and annual periods.

\section{Introduction}

Climate is one of the most important factors affecting human life from past to present. Climate has a huge impact on people's daily lifestyles (Thompson and Perry 1997). There is a strong relationship between the distribution of the earth surface, people's food and clothing preferences, shelter needs, and urban climate, which has an important role in the development of human character, and bioclimatic comfort (Insaf et al. 2013; Kim et al. 2017). Characteristic climatic events such as urban climate and urban heat island that occur in cities create different physical and psychological environments for those living in cities. Urban climate can increase thermal stress of urban residents, especially during summer (during heat waves), while it reduce thermal stress in winter (Gulyás et al., 2006).

Fossil fuel use, population growth, urbanization, wrong land use, unconscious disposal of wastes in nature and deforestation have brought many environmental problems, especially global warming. Global warming caused by climate change has negative effects on many factors such as ecosystems, living beings and water resources (Mansuroglu et. al. 2021). Heat stress, excessive precipitation, inland and coastal floods, landslides, air pollution, drought and water scarcity are the biggest threats to urban areas (IPCC, 2014). High temperature, poor air quality and strong wind caused by climate change can cause heatstroke, shortness of breath and injuries, respectively (Karakounos et al., 2018).

In recent years, urban climate studies have been given great importance in order to reveal the effects of climate factor on cities and people living in cities and the dimensions of global warming. Urban climate studies cover a wide range of research categories, including the evaluation of thermal comfort with the aim of improving urban sustainability. Actually, there is an increasing interest in this issue due to the fact that more than half of the world's population lives in cities and the percentage of urban population is increasing (Ichim and Sfîcă, 2020).

The most commonly used concept within the scope of urban climate studies is the concept of bioclimatic comfort. The concept of bioclimatic comfort is defined as the conditions in which people adapt to their environment by spending the least energy (Cetin et al. 2010; Cetin et al. 2018). Although there are great differences between climate parameters, air temperature, air humidity, air wind and short-long wave radiations constitute the most important components of bioclimatic comfort. These components are an important factor in people's physiological state and health.

According to Olgyay (2015); while ideal bioclimatic comfort values vary between $21-27.5^{\circ} \mathrm{C}$ in terms of temperature parameter and $30-65 \%$ in terms of relative humidity parameter, this value is known as $5 \mathrm{~m} / \mathrm{sec}$ for wind speed parameter. In a study on Turkey; It has been found that ideal temperature values should be between $16.7^{\circ} \mathrm{C}$ and $24.7^{\circ} \mathrm{C}$ in order to provide a comfortable environment for people in terms of climate. It has been emphasized that in determining the comfort zone, the wind speed below $6 \mathrm{~m} / \mathrm{s}$ and the relative humidity value between $30 \%$ and $70 \%$ should be taken into account, as well as the temperature values (Güçlü, 2008). According to recent studies; The temperature range for bioclimatic comfort in Turkey has been determined between 17.0 and $24.9^{\circ} \mathrm{C}$, and this perceived temperature range is located in the middle latitudes (Sen and Genc, 2017; Yucedag et al. 2019).

Meteorological parameters have an important role in guiding urban studies in the fields of landscape architecture, landscape management, landscape planning, landscape design and city planning. People can choose new residential areas by using bioclimatic maps and provide a comfortable environment suitable for them at comfortable temperature values (Cetin et. al., 2018). These maps provide invaluable reference information in urban and rural planning, ecological and economic decision making, land use planning, recreation and tourism planning studies. Considering the dimensions of urbanization, such maps can provide important clues in determining the most suitable places for recreation and residential areas (Olgyay 2015; Topay and Parladir 2015).

Svensson et al. (2003) used the PET index based on meteorological methods to determine the relationship between bioclimatic comfort zones and land use areas in Gothenburg, Sweden. According to the findings obtained from this study; It has been determined that the problem affecting bioclimatic comfort in Scandinavia is the wind speed and wind chill. The highest PET values in the study area were found in central residential areas, while the lowest PET values were determined in coastal and green areas. Emmanuel (2005) examined the relationship between residential areas and thermal comfort conditions determined based on THI and RSI (Relative Strain Index) in Sri Lanka. The findings of the researcher showed that climatic sensitivity is taken into account in urban design for tropical areas. Toy et. al (2007) used THI to determine the relationship between rural, urban and urban forest areas and bioclimatic conditions in Erzurum, Turkey. According to the researcher; It has been determined that the most suitable areas for human comfort in Erzurum conditions are the urban forest and the urban area followed by the rural areas throughout the entire period.

Kantor and Unger (2010), in their study on the suitability of resting places in urban areas in terms of thermal comfort, revealed the relationship between the thermal conditions determined based on PET and the land use model. The study emphasized that it would be easy to calibrate the area model, to calculate the comfort indices from the measured meteorological parameters, or to simulate the thermal conditions of the investigated area with the use of ENVI-Ray or

Page $2 / 22$ 
RayMan software. Danisvar et al. (2013) evaluated bioclimatic comfort conditions in Iran based on PET method. The study concluded that bioclimatic comfort conditions in the country occur mostly in spring, the researcher emphasized that areas with an altitude between 1000 and $2000 \mathrm{~m}$ have better conditions. Ahmadi and Ahmadi (2017) obtained thermal comfort maps by using meteorological parameters of 43 meteorological stations of Iran between 1970-2013. Researchers have demonstrated bioclimatic comfort mapping (BCM) of the study area based on bioclimatic indices such as Temperature Humidity Index (THI), Effective Temperature (ET) and Relative Strain Index (RSI). According to the results of the researchers; Thermal comfort in the northern and western half of Iran is higher than in the southern and eastern parts of the country. The ET and THI results divided the whole country into six regions, ranging from regions with thermal comfort deficiency to regions with thermal comfort conditions. The study concluded that there are no thermal comfort conditions for most of the year in the middle and southeastern regions of the country as well as the southern part of it. In the study by Vinogradova (2020), UTCI was applied to evaluate the bioclimatic situation in Russia. According to the results obtained by the researcher; It has been determined that all cold stress and all heat stress categories are observed in Russia, but cold stress conditions are more dominant. In summer, heat stress and uncomfortable conditions were observed in most of Russia. In most of the country, the maximum UTCI values for the study period corresponded to mild and strong heat stress. Cetin and Sevik (2020) investigated the relationship between land use and bioclimatic comfort zones determined based on PET index in Trabzon province using GIS and prolonging sensing technologies. Bioclimatic comfort maps produced for the years 1985, 1994, 2005 and 2018 and CORINE land use maps belonging to the same years were evaluated together. In the study conducted by Gungor et al. (2021), The bioclimatic comfort areas of Mersin city center between 1972 and 2018 were revealed depending on the PET index. Meteorological parameters such as surface and air temperature, wind speed and relative humidity were taken into account in PET calculations. According to the results of the study; As a city station, PET values increased in areas close to water in Mersin, while a decreasing trend was observed in rural areas.

This study aims to reveal the relationship between bioclimatic comfort zones determined based on environmental climate parameters (ECP) and bioclimatic indices (PET, THI, UTCI,) and land use changes in Sivas province. In the study, meteorological data of Sivas province for the years 1990 and 2018 and the CORINE land cover data of the relevant years were used.

\section{Material And Method}

\subsection{The study area}

The province of Sivas is located in Central Anatolia's upper Kzlrmak Region. The province, which has an area of 28.488 km2 and is Turkey's second largest after Konya, is located between 360 and 390 east longitudes and 380 and 410 north latitudes (Figure 1). Sivas province, in general, is shaped like a plateau, with valleys between single mountains or mountain groups, sunken plains, and hills. The province of Sivas is the coldest in Central Anatolia. Summers are hot and dry, while winters are bone-chillingly cold. Summer is a short period. There are significant temperature changes between the summer and winter seasons, as well as between day and night. In the summer, the temperature can reach 40 degrees Celsius, while in the winter, it can plunge to - 33 degrees Celsius. The study area generally shows a structure rising towards the north-northeast and south-southeast of the city center. The height of the study area above sea level varies between 581 and $3.012 \mathrm{~m}$ (Figure 1).

When the population data of the study area in the reference years are examined; the population of the province in 1990 was 767,481 , but it decreased by $15.75 \%$ to 646,608 in 2018 . While the rural population ratio of the province decreased from $50.23-27.22 \%$ in the relevant years; urban population ratio increased from $49.77-72.78 \%$ (TSI, 2021; Table 1).

Table 1

Population Structure of Sivas Province in Reference Years (TSI, 2021)

\begin{tabular}{|c|c|c|c|c|c|c|c|c|}
\hline Years & 1990 & & & & 2018 & & & \\
\hline \multirow[t]{2}{*}{$\begin{array}{l}\text { Population } \\
\text { Structure }\end{array}$} & $\begin{array}{l}\text { Rural }^{1} \\
\text { Population }\end{array}$ & Ratio (\%) & Urban $^{2}$ Population & Ratio (\%) & Rural Population & Ratio (\%) & Urban Population & Ratio (\%) \\
\hline & 385.534 & 50.23 & 381.947 & 49.77 & 176.019 & 27.22 & 470.589 & 72.78 \\
\hline Total population & 767.481 & & & & 646.608 & & & \\
\hline
\end{tabular}

[1] Rural population: Population in settlements (including town municipalities) outside the provincial and district centers

[2] Urban population: Population within the boundaries of provincial and district centers

\subsection{Data supply and software}

In this study, environmental climate parameters such as temperature (T), relative humidity (RH) and wind speed (WS) for the years 1990 and 2018 of 9 meteorology stations located in Sivas province were used for bioclimatic comfort analysis. Detailed information about the meteorology stations is given in Table 2, and the spatial distribution of the meteorology stations is shown in Figure 1. Annual average values were obtained by using monthly average values for the environmental climate parameters (ECP) of the relevant time periods, which were obtained from the Sivas Meteorology Provincial Directorate (TSMS, 2018). For all time periods, analyzes of 5 periods of environmental climate parameters, namely annual, winter, spring, summer and autumn periods, were carried out. 12-month average; the average of December, January and February; the average of March, April and May; the average of June, July and August; and the average of September, October and November were used for annual analysis, winter season analysis, spring season analysis, summer season analysis and autumn season analysis, respectively.

In order to determine the relationship between bioclimatic comfort and land use, land use data for the years 1990 and 2018 covering the study area were used. Land use data for the relevant years of the study area were obtained within the scope of the Coordination of Information on the Environment program

Page 3/22 
(CORINE) coordinated by the European Union (CORINE, 2021).

Excell 2017 software was used for all analyzes of temperature ( $T$ ), relative humidity $(\mathrm{RH})$ and wind speed (WS) environmental climate parameters (annual and 4 seasons) and Thermo Hygrometric Index (THI) calculations used in the study. Rayman 1.2 software was used for Physiological Equivalent Temperature (PET) calculations (Błazejczyk, 1994), and Bioclima 2.6 software was used for Universal Thermal Climate Index (UTCl) calculations (Błazejczyk, 2017). Within the scope of the CORINE program data, ArcGIS 10.2 software was used to obtain the land use data of the relevant years in the study area.

Table 2

The average meteorological data of Sivas province in the climate period (1990-2018)

\begin{tabular}{|llllllll|}
\hline Station Code & Station name & Latitude & Longitude & Altitude $(\mathrm{m})$ & AAT $\left({ }^{\circ} \mathrm{C}\right){ }^{*}$ & AARH $(\%) *$ & AAWS $(\mathrm{m} / \mathrm{s}) *$ \\
\hline 17090 & Sivas & 39.74 & 37.00 & 1294 & 9.54 & 65.54 & 1.17 \\
\hline 17762 & Kangal & 39.24 & 37.39 & 1521 & 6.99 & 68.01 & 2.14 \\
\hline 17684 & Suşehri & 40.16 & 38.08 & 1164 & 10.43 & 56.75 & 2.82 \\
\hline 17716 & Zara & 39.88 & 37.73 & 1338 & 8.77 & 64.49 & 1.88 \\
\hline 17734 & Divriği & 39.36 & 38.11 & 1121 & 11.69 & 57.49 & 2.24 \\
\hline 17162 & Gemerek & 39.19 & 36.08 & 1182 & 9.89 & 64.42 & 1.47 \\
\hline 17841 & Gürün & 38.72 & 37.27 & 1401 & 9.32 & 57.92 & 2.68 \\
\hline 18139 & Şarkışla & 39.33 & 36.44 & 1253 & 9.52 & 65.57 & 2.63 \\
\hline 17710 & Ulaş & 39.44 & 37.03 & 1528 & 8.49 & 69.71 & 2.41 \\
\hline
\end{tabular}

*Annual average values were obtained using monthly average values, Annual Average Temperature: AAT, Annual Average Relative Humidity: AARH, Annual Average Wind Speed: AAWS

\subsection{Method}

The basis of the method applied in this study is to reveal the relationship between the bioclimatic comfort zones, which are determined and mapped depending on the environmental climate parameters and bioclimatic indices of the study area, and the land use in the study area. Details regarding the determination of bioclimatic comfort value ranges depending on ECP, the calculation of bioclimatic index (PET, UTCI and THI) values, and the creation of spatial distribution maps for the relevant parameters and indices are given below.

\subsubsection{ECP-based BCM analysis}

Temperature ( $\mathrm{T}$ ), relative humidity (RH) and wind speed (WS) parameters were used to determine the bioclimatic comfort zones in Sivas province depending on environmental climate parameters. Table 3 shows the environmental climate parameter (ECP) ranges in terms of bioclimatic comfort. Values with a range of $15-20^{\circ} \mathrm{C}$ in terms of temperature parameter, $30-65 \%$ in terms of relative humidity and $0-5 \mathrm{~m} / \mathrm{s}$ in terms of wind speed parameter were given a score of " 1 " in the study area and the areas with these values were defined as "Comfortable" in terms of bioclimatics. The temperature ( $\mathrm{T})$, relative humidity (RH) and wind speed (WS) values outside the areas defined as bioclimatically comfortable were assigned a score of "0" and these areas were also defined as "Uncomfortable" in terms of bioclimatics (Table 3)

Table 3

Environmental parameter ranges and scores for bioclimatic comfort (Çetin, 2015; Zengin et al., 2010)

\begin{tabular}{|lll|}
\hline Parameter & Ranges & Scores for bioclimatic comfort \\
\hline Temperature $\left({ }^{\circ} \mathrm{C}\right)$ & $<15$ & 0 (Uncomfortable) \\
& $15-20$ & 1 (Comfortable) \\
& $>20$ & 0 (Uncomfortable) \\
\hline Relative humidity $(\%)$ & $<30$ & 0 (Uncomfortable) \\
& $30-65$ & 1 (Comfortable) \\
& $>65$ & 0 (Uncomfortable) \\
\hline Wind speed $(\mathrm{m} / \mathrm{s})$ & $<0$ & 0 (Uncomfortable) \\
& $0-5$ & 1 (Comfortable) \\
& $>5$ & 0 (Uncomfortable) \\
\hline
\end{tabular}

\subsubsection{BCM analysis based on bioclimatic indices}

In this study, PET, UTCI and THI indices were used to determine suitable areas of Sivas province in terms of bioclimatic comfort, depending on bioclimatic indices. In order to calculate these indices, monthly average values of temperature ( $T$ ), relative humidity (RH) and wind speed (WS) parameters were used to obtain annual and four-season average values of these indices. Bioclimatic comfort areas of Sivas province were evaluated depending on the annual and 
four-season average values of these bioclimatic indices. Table 4 and Table 5 show the thermal evaluation ranges of the PET, UTCI and THI indices, respectively. According to Table 4; Evaluation ranges of PET and UTCl indices are divided into 9 and 10 groups, respectively (Zare et al. 2018), and according to Table 5, evaluation range of THI index is divided into 8 groups (lonac et al., 2012).

Physiological equivalent temperature (PET) indice: PET is the most widely used bioclimatic indice in thermal comfort analysis. It was developed based on temperature (T), relative humidity (RH) and wind speed (WS) parameters, (Matzarakis et al., 2010). The most important advantage of the PET indice compared to other thermal indices is that the PET indice is expressed in units of temperature $\left({ }^{\circ} \mathrm{C}\right)$, making it easier to understand the results obtained (Matzarakis et al., 1999; Daneshvar et al., 2013). PET also helps tourists understand their thermal perceptions of weather conditions (Daneshvar et al., 2013). The steps followed in PET calculation are as follows (Çetin et al., 2019; Matzarakis et al. 2010; Erkek et al., 2020

- Obtaining daily temperature $(\mathrm{T})$, relative humidity $(\mathrm{RH})$ and wind speed (WS) data of meteorology stations,

- Finding the annual and four-season averages by taking the arithmetic averages of the daily data of the temperature $(\mathrm{T})$, relative humidity $(\mathrm{RH})$ and wind speed (WS) parameters,

- Lowering the temperature values to sea level with the help of the formula given in Equation (1) below,

$T d=T i+(h i * 0.005) \quad(1)[3]$

The next step is to convert the temperature, relative humidity and wind values lowered to sea level with the help of the above equation (1) into PET values with the help of RayMan 1.2 software. For the PET index, the corresponding PET value for the "coldest" thermal class is lower than $4^{\circ} \mathrm{C}$, while the corresponding PET value for the "hottest" thermal class is greater than $41^{\circ} \mathrm{C}$. PET values in the $18-23^{\circ} \mathrm{C}$ range represent the "comfortable" class (Table 4$)$.

Universal Thermal Climate Index (UTCI): UTCI was developed by the International Society of Biometeorology (ISB) Commission with the support of the European Union to evaluate the thermal environmental conditions in the external environment primarily for use in the field of human biometeorology (Vinogradova, 2020; Błażejczyk et al., 2013; Jendritzky et al. ., 2012). UTCl is accepted as the equivalent temperature for the environment obtained from a reference environment. It is defined as the air temperature of the reference environment that produces the same strain index value when compared to the response of the reference individual to the real environment. It is one of the most widely used indexes to calculate heat stress in outdoor spaces (Blazejczyk, 1994). UTCl index can be calculated by using dry temperature, average radiation temperature, water vapor pressure or by using dry temperature, relative humidity and wind speed (Zare et al. 2018).

For the UTCI index, the corresponding UTCI value for the "coldest" thermal class is values lower than $-40^{\circ} \mathrm{C}$, while the corresponding UTCI value for the "hottest" thermal class is values greater than $+46^{\circ} \mathrm{C}$. UTCI values in the range of $9-26^{\circ} \mathrm{C}$ represent the "no thermal stress" class (Table 4$)$.

Table 4. Comparing thermal perceptions of bioclimatic indices used in the study (Zare et al., 2018)

\begin{tabular}{|c|c|c|c|}
\hline \multirow[b]{2}{*}{ Thermal Perception } & \multicolumn{2}{|c|}{ Indices $\left({ }^{\circ} \mathrm{C}\right)$} & \multirow{2}{*}{$\begin{array}{c}\text { Color } \\
\text { Levels }\end{array}$} \\
\hline & PET & UTCI & \\
\hline Very Cold ${ }^{1}\left(\right.$ Extreme Cold Stress $\left.s^{1,2}\right)$ & $<4$ & $<-40$ & \\
\hline (Very Strong Cold Stress ${ }^{2}$ ) & & -40 to -27 & \\
\hline Cold $^{1}$ (Strong Cold Stress ${ }^{1,2}$ ) & $4-8$ & -27 to -13 & \\
\hline Cool $^{1}$ (Moderate Cold Stress ${ }^{1,2}$ ) & $8-13$ & -13 to 0 & \\
\hline Slightly Cool ${ }^{1}$ (Slight Cold Stress ${ }^{1,2}$ ) & $13-18$ & 0 to +9 & \\
\hline Comfortable $^{1}$ (No Thermal Stress ${ }^{1,2}$ ) & $18-23$ & +9 to +26 & \\
\hline Slightly Warm ${ }^{1}$ (Slight Heat Stress $\left.{ }^{1}\right)$ & $23-29$ & & \\
\hline Warm $^{1}$ (Moderate Heat Stress ${ }^{1,2}$ ) & $29-35$ & +26 to +32 & \\
\hline Hot $^{1}$ (Strong Heat Stress ${ }^{1,2}$ ) & $35-41$ & +32 to +38 & \\
\hline (Very Strong Heat Stress ${ }^{2}$ ) & & +38 to +46 & \\
\hline Very $\operatorname{Hot}^{1}\left(\right.$ Extreme Heat Stress $\left.{ }^{1,2}\right)$ & $>41$ & $>+46$ & \\
\hline
\end{tabular}

\section{Note: ${ }^{1} \mathrm{PET} \quad{ }^{2} \mathrm{UTCl}$}

Thermo Hygrometric Index (THI): This index, whizh is suggested by Thom (1959), can be used most widely in bioclimatic studies and is accepted as an indicator of temperature humidity. This index is used in microclimatology studies to evaluate the effect of different temperature and humidity levels on human comfort. THI can be calculated with the help of the formula in Equation (2) below (Ahmadi and Ahmadi, 2017; Emmanuel, 2005).

$T H I=0,8 * T+\left(R H^{*} T / 100\right)$

(2) [4]

For the THI index, the corresponding $\mathrm{THI}$ values for the "coldest" thermal class are values between $-20^{\circ} \mathrm{C}$ and $-10{ }^{\circ} \mathrm{C}$, while the corresponding $\mathrm{THI}$ values for the "hottest" thermal class are values greater than $30^{\circ} \mathrm{C}$. THI values in the $15-20^{\circ} \mathrm{C}$ range represent the "comfortable" class (Table 5).

Table 5. The value classes and the associated bioclimatic comfort of THI (lonac et al., 2012) 


\begin{tabular}{ccc}
\hline Thermal Perception & THI $\left({ }^{\circ} \mathbf{C}\right)$ & $\begin{array}{c}\text { Color } \\
\text { Levels }\end{array}$ \\
\hline Excessively Cold & $-20<\mathrm{THI} \leq-10$ & \\
Very Cold & $-10<\mathrm{THI} \leq-1.8$ & \\
Cold & $-1.8<\mathrm{THI} \leq 13$ & \\
Cool & $13<\mathrm{THI} \leq 15$ & \\
Comfortable & $15<\mathrm{THI} \leq 20$ & \\
Hot & $20<\mathrm{THI} \leq 26.5$ & \\
Very Hot & $26.5<\mathrm{THI} \leq 30$ & \\
Sultry & $\mathrm{THI}>30$ & \\
\hline
\end{tabular}

\subsubsection{GIS-based $B C M$ analysis}

In the study, the Inverse Distance Weighting (IDW) method in the Spatial Analysis module of ArcGIS 10.2 software was used to create the spatial distribution maps of the biolimatic comfort areas depending on environmental climate parameters and bioclimatic indices (PET, UTCI and THI).

Temperature, relative humidity and wind speed parameters, which are effective in determining suitable areas in terms of bioclimatic comfort based on environmental climate parameters, were reclassified with the help of ArcGIS 10.8 software according to the suitability scores in terms of bioclimatic comfort (1 or 0 ) in Table 2. The reclassified thematic maps were heavily overlapped by evaluating them together according to the factor weight of each environmental climate parameter with the help of the "Weighted Overlay" module of ArcGIS 10.2 software. Spatial distribution maps showing the suitable areas of Sivas province in terms of bioclimatic comfort were created depending on the environmental climate parameters in line with the weights of these factors.

The calculated values of PET, UTCI and THI indices, which were taken into account in the evaluation of biolimatic comfort zones related to bioclimatic indices, were reclassified with the help of ArcGIS 10.8 software according to the evaluation intervals of each index in Table 3 and Table 4 . The color levels given in Table 4 and Table 5 for the evaluation intervals of all three indices were used as a reference in showing the spatial distribution of these indices.

The determination of the relationship between bioclimatic comfort zones and land use was performed with the help of the Zonal tool in the Spatial Analyst plugin of ArcGIS 10.8 software.

\subsubsection{CORINE land use/cover mapping}

The CORINE land use/cover classification is designed to include various land covers of European Union (EU) countries. The CORINE land cover classification is a classification that is standard for the whole of Europe and defines a land cover of 44 classes arranged hierarchically at three levels. The first level corresponds to the five main classes (artificial areas, agricultural fields, forests and semi-natural areas, wetlands, water bodies). The second level (15 classes) corresponds to land covers (urban areas, forests, lakes, etc.) with a higher level of detail, covering physical and physiognomic entities. The third level consists of 44 classes (Willems et al., 2000; Yılmaz, 2010).

In this study; Within the scope of CORINE land use/cover classes, the land use classes of the study area for the years 1990 and 2018 were arranged as 6 classes (natural and semi-natural areas, forested areas, water structures, agricultural areas, artificial areas and residential areas). In this classification, industry-trade-transportation areas, mine-dump-construction areas, non-agricultural green areas were taken into consideration within the scope of "artificial areas". Maquis and herbaceous plants, open areas that are not covered with vegetation or covered with a small amount of vegetation (bare rocks, sparsely planted areas, etc.) were evaluated within the scope of "natural areas and semi-natural areas". Lake areas such as rivers and dams are taken into consideration within the scope of "water structures".

[3] Td : Temperature reduced to sea level; Ti : Average temperature of the station; hi : the height of the station

[4] THI: Termo Higrometrik Indeks; $T$ : Hava sıcaklığı ( $\left.{ }^{\circ} \mathrm{C}\right) ; R H:$ Nisbi nem (\%)

\section{Results}

\subsection{Spatial Distribution of Environmental Climate Parameters (T, RH and WS)}

Temperature. When the map (Figure 2) regarding the distribution of 1990 average temperature data of the province is examined; the average temperature of the year in the province varies between 5.95 and $10.89^{\circ} \mathrm{C}$; It is seen that the areas with the lowest average temperature range are in Kangal district and its surroundings $\left(5.95-7.27^{\circ} \mathrm{C}\right)$, and the areas with the highest temperature range are located in Divriği district and its surroundings. The lowest average temperature band detected in the province in 1990 was found as -6.96 to $-5.14{ }^{\circ} \mathrm{C}$ during the winter months, while the highest average temperature values were determined as $21.17-22.33^{\circ} \mathrm{C}$ in the summer months.

According to the distribution of the average temperature data of the province in 2018 , the annual average temperature of the province increased by an average of $3{ }^{\circ} \mathrm{C}$ compared to 1990 and It varied between $9.24^{\circ} \mathrm{C}-13.64^{\circ} \mathrm{C}$. It was determined that the areas with the lowest average temperature range are in and around Kangal district $\left(9.24^{\circ} \mathrm{C}-10.34^{\circ} \mathrm{C}\right)$, while the highest average temperature range $\left(12.43^{\circ} \mathrm{C}-13.64^{\circ} \mathrm{C}\right)$ was concentrated in Divriği district and its surroundings. The average temperature of Sivas city center and its surroundings in 2018 is between $11.57^{\circ} \mathrm{C}$ and $12.43^{\circ} \mathrm{C}$. The annual average temperature of the city center and its surroundings has increased by an average of $3.4^{\circ} \mathrm{C}$ compared to 28 years ago. The lowest average temperature band detected in the province in 2018 was found between -0.79 and $-0.21^{\circ} \mathrm{C}$ in winter months, while the highest average temperature values were determined as $22.53^{\circ} \mathrm{C}-23.96^{\circ} \mathrm{C}$ 
in the summer months. It is understood that there was a decrease in the lowest temperature values and and upward trend in the highest temperature values of the province in the last 28 years (Figure 2).

Relative humidity: When the relative humidity map of the year 1990 (Figure 3), which was created on the basis of the relative humidity data of 9 different meteorology stations of the province, is examined; It will be seen that the annual average relative humidity value is between $53.83 \%$ and $81.73 \%$. The areas with the highest annual average relative humidity (73.74\%-81.73\%) are in Ulaş and its surroundings, while the areas with the lowest annual average relative humidity (53.83\%-59.63\%) are concentrated around Divriği and Gurun. The average relative humidity value of Sivas city center and its surroundings is between $64.22 \%$ and $68.49 \%$. In the relevant year, the lowest average relative humidity values in the province were determined in the summer period, while the highest relative humidity values were found in autumn and winter.

According to the average relative humidity distribution map of 2018; The average relative humidity values of the year are in the band of $55.52 \%-69.53 \%$. The areas with the highest annual average relative humidity (66.12\%-69.53\%) are around Kangal and Sarkisla, while the lowest values (55.52\%-59.64\%) are concentrated around Divrigi. From 1990 to 2018, the annual relative humidity of the province decreased by $10 \%$ on average depending on the temperature increase in the relevant years. The average relative humidity value of Sivas city center and its surroundings decreased by an average of $5 \%$ and was found to be between $59.64 \%$ and $62.50 \%$ (Figure 3 ).

Wind speed: When the distribution map of the 1990 average wind speed data of the province (Figure 4) is examined; It is understood that the annual average speed of the province varies between $1.25 \mathrm{~m} / \mathrm{sec}$ and $3.48 \mathrm{~m} / \mathrm{sec}$. Regions with the lowest average wind speed (1.25-1.87 m/sec) are in Sivas city center and its surroundings, while the highest values $(2.95-3.48 \mathrm{~m} / \mathrm{sec}$ ) are concentrated in and around Gürün and Suşehri districts. The lowest average wind speed values $(0.76-1.27 \mathrm{~m} / \mathrm{sec})$ were found in autumn, while the highest values $(3.76-4.63 \mathrm{~m} / \mathrm{sec})$ were determined in the summer months.

Average wind speed values for 2018, which has a decreasing trend compared to 1990 , are between $0.97 \mathrm{~m} / \mathrm{s}$ and $3.19 \mathrm{~m} / \mathrm{s}$. The lowest average wind speed of the province $(0.97 \mathrm{~m} / \mathrm{s}-1.56 \mathrm{~m} / \mathrm{s})$ in the relevant year is concentrated in Sivas city center and its surroundings, as in 1990. The regions with the highest average wind speed values $(2.48-3.19 \mathrm{~m} / \mathrm{s})$ are around Ulaş and Gürün. The lowest values $(0.76-1.27 \mathrm{~m} / \mathrm{s})$ are in autumn, while the highest values (2.98-3.75 $\mathrm{m} / \mathrm{sec}$ ) were detected in the summer months, as in 1990 (Figure 4).

\subsection{Spatial Distribution of Bioclimatic Comfort Zones}

The bioclimatically comfortable areas in Sivas differ according to the environmental climate parameters (ECP) and bioclimatic indices (PET, THI, UTCI) used in the study. In this section, the spatial distribution of bioclimatic comfort areas based on the relevant parameters and indices is interpreted.

\subsubsection{Spatial Distribution of Bioclimatic Comfort Zones Based on Environmental Climate Parameters (CIP-ECP)}

Considering the analysis made according to the annual average data of the bioclimatic comfort areas based on the environmental climate parameters of the study area, it is seen that comfortable areas increased in 2018 compared to 1990 . When the change of comfort areas according to the seasons is examined, it was concluded that the whole of the province is not comfortable in terms of bioclimatics in the winter period in both years. In addition, it was found that comfortable areas increased in spring and autumn, and bioclimatic comfort areas decreased in summer (Figure 5).

\subsubsection{Spatial Distribution of Bioclimatic Comfort Zones Based on Bioclimatic Indexes}

Physiological Equivalent Temperature Index (PET)

Considering the analysis made according to the annual average data of the bioclimatic comfort areas based on Physiological Equivalent Temperature (PET) Index of the study area, it is seen that cool areas dominate in both years, and in terms of bioclimatic comfort in 1990, the cold areas turned into cool areas in 2018. When the change of comfort areas according to the seasons is examined, it was found that the whole province is in the very cold category in both years and is not comfortable in terms of bioclimatics. The regions that were cold in the spring of 1990 were included in the category of cool regions in 2018 . In the autumn season, almost all of the province is in the cool category in 1990, while in 2018, it is seen that the surroundings of Gürün and Divriği moved to the slightly cool category. In the summer months, almost all of the province was found to be suitable in terms of bioclimatic comfort in 1990, while in the same period of 2018, it was concluded that the surroundings of Gurun and Divriği warmed up more than in 1990 (Figure 6).

Thermo Hygrometric Index (THI)

When the annual map prepared according to the Thermo Hygrometric Index (THI) is evaluated (Figure 7), it is seen that cold and cool areas were dominant in terms of bioclimatic comfort in 1990; In 2018, it was observed that these areas turned into comfortable areas, except for Kangal and its surroundings. When the change of comfort areas according to the seasons is examined, it was determined that the city, which was very cold in the winter of 1990 , turned into the cold category in 2018 and was not comfortable in terms of bioclimatics in this period.

While cold regions were dominant in almost all of the province in the spring of 1990, it was determined that most of these areas turned into comfortable areas in 2018. In the summer of 1990, it was determined that these areas, which were hot and very hot areas, turned into comfortable and cool areas in 2018 . In the autumn season, it was concluded that almost every region of the province was comfortable except for Kangal and Gurun areas in 1990 and Kangal district in 2018 (Figure 7).

Universal Thermal Climate Index (UTCI)

Page $7 / 22$ 
When the annual map prepared according to the Universal Thermal Climate Index (UTCI) is examined (Figure 8), it is seen that the entire province was under slight cool stress in 1990. However, in 2018 it was observed that some of these areas (regions in the north-eastern and western parts of the province) turned into areas that are not under any thermal stress and are suitable in terms of bioclimatic comfort. When the change of comfort areas according to the seasons is examined, it was determined that while moderately cold stressed areas were dominant in almost all of the province in the winter of 1990 , there was a transformation into slightly stressed areas in Sivas city center and Gemerek and Suşehri districts in 2018. In the spring of 1990, areas with slight cold stress spread in almost all of the province, except for Gürün and Kangal. However, it is understood that the bioclimatic comfort classification of Sivas city center, Gemerek, Divriği and Suşehri has changed in 2018 and there is no thermal stress in these regions. While there was no thermal stress in the whole province in both years during the summer period, it is observed that there was a change from 1990 to 2018 in the autumn months from areas with slight cold stress to areas without any thermal stress (Figure 8).

\subsection{Spatial Distribution of Land Use/Cover}

When Figure 9 and Table 6 regarding the land use classes of the province in 1990-2018 are examined, it is seen that the land use type that covers the most area in the province in both years is natural-semi-natural areas and agricultural areas. From 1990 to 2018, an increase was observed in natural and seminatural areas, water bodies, artificial and urban areas, as well as a decrease in forest areas and agricultural areas (Figure 9, Table 6).

Table 6

Changes in land use/cover obtained CORINE land use/land cover data

\begin{tabular}{|c|c|c|c|c|c|}
\hline \multirow{4}{*}{$\begin{array}{l}\text { Land use/cover } \\
\text { (LULC) classes }\end{array}$} & \multicolumn{2}{|l|}{1990} & \multicolumn{2}{|l|}{2018} & \multirow[t]{4}{*}{ Changes (\%) in LULC for $1990-2018$} \\
\hline & \multirow{2}{*}{\multicolumn{2}{|c|}{$\begin{array}{l}\text { Area of } \\
\text { LULC }\end{array}$}} & \multirow{2}{*}{\multicolumn{2}{|c|}{$\begin{array}{l}\text { Area of } \\
\text { LULC }\end{array}$}} & \\
\hline & & & & & \\
\hline & $\mathrm{km}^{2}$ & $\%$ & $\mathrm{~km}^{2}$ & $\%$ & \\
\hline Natural and Semi-Natural Areas & 15437,39 & 54,81 & 15530,97 & 55,14 & 0,33 \\
\hline Forest Areas & 1122,23 & 3,98 & 1072,18 & 3,81 & $-0,18$ \\
\hline Water Body & 99,56 & 0,35 & 175,64 & 0,62 & 0,27 \\
\hline Agricultural Areas & 11402,46 & 40,49 & 10880,21 & 38,63 & $-1,85$ \\
\hline Artificial Areas & 22,51 & 0,08 & 87,81 & 0,31 & 0,23 \\
\hline Urban/Built Areas & 80,42 & 0,29 & 120,67 & 0,43 & 0,14 \\
\hline Total & $28.164,56$ & 100 & 28164,56 & 100 & 0 \\
\hline
\end{tabular}

\subsection{Evaluation of the Relationship Between Bioclimatic Comfort and Land Use}

According to the annual climate data of the ECP

It was concluded that while the land use type with the highest overlap in terms of bioclimatic comfort in 1990 was natural-semi-natural areas (with a value of $59.85 \%$ ), only $21.28 \%$ of the urban areas in the relevant year were suitable in terms of bioclimatic comfort. In 2018 , the land use type where the highest overlap is experienced with areas suitable for bioclimatic comfort was forest areas. From 1990 to 2018, it was determined that the areas suitable for bioclimatic comfort in urban areas increased and reached $73.49 \%$ (Table 7-Table 8).

In 1990, the period with the highest bioclimatic comfort was the summer period. In this period, it was found that the rate of areas suitable for bioclimatic comfort in all land use types (forest areas, water bodies, agricultural areas, artificial areas and urban areas) except natural and semi-natural areas is over $90 \%$. While $96.30 \%$ of urban areas were suitable in terms of bioclimatic comfort in the summer period of 1990, all land use types were not suitable in terms of bioclimatic comfort in the winter period. According to the relevant parameter, it was determined that the highest level of comfortable areas in all land types was spring in 2018 , and $89.16 \%$ of urban areas were bioclimatically comfortable in the relevant period (Table 7-Table 8).

According to PET index

It is seen that the period with the highest number of comfortable areas in 1990 was the summer period. In the relevant period, it was determined that $99.18 \%$ of natural-semi-natural areas, $100 \%$ of forest areas, $97.78 \%$ of water bodies, $97.88 \%$ of agricultural areas, $93.12 \%$ of artificial areas and $91.67 \%$ of urban areas are bioclimatic comfortable areas. Looking at the relationship between the comfort values of the relevant index for 2018 and the land cover of the same year, it will be seen that the most comfortable areas are again in the summer period. In the relevant period, It was found that biologically comfortable areas constitute; $72.66 \%$ of natural-semi-natural areas, $98.36 \%$ of forest areas, $97.90 \%$ of water bodies, $89.04 \%$ of agricultural areas, $85.19 \%$ of artificial areas and $92.17 \%$ of urban areas (Table 8$)$.

According to THI index

In 1990, it was determined that the period with the highest level of comfortable areas was the autumn period. In the relevant period, It was found that biologically comfortable areas constitute; $78.84 \%$ of natural-semi-natural areas, $97.60 \%$ of forest areas, $98.52 \%$ of water bodies, $78.52 \%$ of agricultural areas and $75.86 \%$ of artificial areas. When the comfort values of the relevant index for 2018 are examined, it will be seen that the most comfortable areas are again in the autumn period. it was determined that $98.39 \%$ of natural-semi-natural areas, $100 \%$ of forest areas, $99.58 \%$ of water bodies, $96.46 \%$ of agricultural areas 
and $98.15 \%$ of artificial areas are bioclimatic comfortable areas. From 1990 to 2018 , it was concluded that the areas suitable for bioclimatic comfort in urban areas increased from $87.05-95.18 \%$ (Table 8).

According to UTCI index

In 1990, it was determined that the period when there was no thermal stress / bioclimatic comfortable areas at the highest rate was the summer period followed by the autumn period. It was found that there is no thermal stress in $100 \%$ of all land use types in the summer period, and all areas are bioclimatically comfortable. In the autumn of the same year, it was seen that that $51.59 \%$ of natural-semi-natural areas, $52.10 \%$ of forest areas, $73.33 \%$ of water bodies, $58.97 \%$ of agricultural areas, $68.98 \%$ of artificial areas and $76.85 \%$ of urban areas are bioclimatic comfortable areas (Table 7 ).

Looking at the comfort values of the relevant index for 2018, it will be seen that the summer period is again the highest in areas without thermal stress, followed by the autumn period and the spring period. It was determined that in the summer period, $100 \%$ of all land use types - as in 1990 - do not have any thermal stress, all areas are comfortable in terms of bioclimatic. In the autumn of the same year, $94.04 \%$ of natural-semi-natural areas, $98.21 \%$ of forest areas, $87.82 \%$ of water bodies, $86.86 \%$ of agricultural areas and $94.45 \%$ of artificial areas were bioclimatic comfortable areas. In this period, it was found that the bioclimatic comfort values of urban areas increased by $14.72 \%$ compared to 1990 . It was determined that $91.57 \%$ of the urban areas in the autumn period of the relevant year and $40.96 \%$ in the spring period were suitable in terms of bioclimatic comfort (Table 8 ).

\section{Conclusion And Discussion}

Physical planning and design processes are usually conducted with the purpose of creating sustainable and environmentally friendly living spaces, and since these processes concentrate on providing optimal living conditions for people while preserving environmental and cultural elements, the impact of bioclimatic comfort on humans and other species is of particular importance for these processes. In this context, it's critical to assess climatic conditions in a way that leads to a more convenient existence and include them into planning. Similarly, the effect of existing land use and physical features on climate is critical, and it is one of the elements that must be taken into account in sustainable design and planning. Therefore, one of the key tasks in the design of sustainable spaces is to investigate the impacts of climate factors and physical characteristics on each other (Çetin and Şevik 2020).

In this study, the general climate data of Sivas province (temperature, relative humidity, wind speed) was evaluated and bioclimatic comfort areas of the province in 1990 and 2018 were determined with the help of ECP and PET, UTCI and THI indexes on the basis of these climate data. These comfort areas were evaluated together with the land use in the reference years. In the study, it was determined that the annual average temperature of the province increased by 3 ${ }^{\circ} \mathrm{C}$ from 1990 to 2018 , while the relative humidity and the wind speed decreased by about $10 \%$ and $0.3 \mathrm{~m} / \mathrm{sec}$, respectively. 
Table 7

Spatial distribution of the relationship between bioclimatic comfort classification based on bioclimatic indices and land use/cover - in 1990

\begin{tabular}{|c|c|c|c|c|c|c|c|c|c|c|c|c|c|}
\hline \multirow{4}{*}{$\begin{array}{l}\text { Bioclimatic } \\
\text { İndices }\end{array}$} & \multirow{4}{*}{$\begin{array}{l}\text { Period } \\
\text { (Season) }\end{array}$} & \multirow{4}{*}{$\begin{array}{l}\text { Bioclimatic } \\
\text { Comfort } \\
\text { Classification }\end{array}$} & \multicolumn{11}{|c|}{ Land Use/Cover Classes } \\
\hline & & & \multirow{2}{*}{\multicolumn{2}{|c|}{$\begin{array}{l}\text { Nat } \\
\text { ural and Semi- } \\
\text { Natural Areas }\end{array}$}} & \multirow{2}{*}{\multicolumn{2}{|c|}{ Forest Areas }} & \multirow{2}{*}{\multicolumn{2}{|c|}{ Water Body }} & \multirow{2}{*}{\multicolumn{2}{|c|}{ Agricultural Areas }} & \multirow{2}{*}{\multicolumn{2}{|c|}{ Artificial Areas }} & \multirow{3}{*}{$\begin{array}{l}\text { UI } \\
\text { Al }\end{array}$} \\
\hline & & & & & & & & & & & & & \\
\hline & & & $\mathrm{km}^{2}$ & $\%$ & $\mathrm{~km}^{2}$ & $\%$ & $\mathrm{~km}^{2}$ & $\%$ & $\mathrm{~km}^{2}$ & $\%$ & $\mathrm{~km}^{2}$ & $\%$ & \\
\hline \multirow[t]{9}{*}{ ECP } & \multirow[t]{2}{*}{ Annual } & Uncomfortable & 6097.12 & 40.15 & 456.87 & 40.56 & 57.10 & 56.29 & 7028.90 & 62.29 & 14.27 & 65.49 & $6 \approx$ \\
\hline & & Comfortable & 9087.07 & 59.85 & 669.52 & 59.44 & 44.33 & 43.71 & 4254.61 & 37.71 & 7.51 & 34.51 & 17 \\
\hline & Winter & Uncomfortable & 15184.19 & 100.00 & 1126.4 & 100.00 & 101.44 & 100.00 & 11283.5 & 100.00 & 21.79 & 100.00 & 81 \\
\hline & \multirow[t]{2}{*}{ Spring } & Uncomfortable & 5906.26 & 38.90 & 410.28 & 36.42 & 53.35 & 52.59 & 7125.08 & 63.15 & 12.77 & 58.60 & 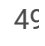 \\
\hline & & Comfortable & 9277.94 & 61.10 & 716.11 & 63.58 & 48.09 & 47.41 & 4158.42 & 36.85 & 9.01 & 41.40 & 31 \\
\hline & \multirow[t]{2}{*}{ Summer } & Uncomfortable & 3143.24 & 20.70 & 59.36 & 5.27 & 2.25 & 2.22 & 994.89 & 8.82 & 0.75 & 3.44 & 3. \\
\hline & & Comfortable & 12040.96 & 79.30 & 1067.03 & 94.73 & 99.18 & 97.78 & 10288.62 & 91.18 & 21.04 & 96.56 & $7 \varepsilon$ \\
\hline & \multirow[t]{2}{*}{ Autumn } & Uncomfortable & 2457.93 & 16.19 & 57.10 & 5.07 & 33.81 & 33.33 & 3683.52 & 32.65 & 12.77 & 58.60 & उद \\
\hline & & Comfortable & 12726.26 & 83.81 & 1069.28 & 94.93 & 67.62 & 66.67 & 7599.99 & 67.35 & 9.01 & 41.40 & 42 \\
\hline \multirow[t]{9}{*}{ PET } & \multirow[t]{2}{*}{ Annual } & Cold & 659.75 & 4.34 & 2.25 & 0.20 & 2.25 & 2.22 & 972.35 & 8.62 & 3.75 & 17.21 & $1 C$ \\
\hline & & Cool & 14530.45 & 95.69 & 1122.64 & 99.80 & 97.68 & 97.78 & 10309.66 & 91.38 & 18.03 & 82.79 & $6 C$ \\
\hline & Winter & Very Cold & 15184.20 & 100.00 & 1126.39 & 100.00 & 101.44 & 100.00 & 11283.51 & 100.00 & 21.79 & 100.00 & 81 \\
\hline & \multirow[t]{2}{*}{ Spring } & Cold & 9300.48 & 61.25 & 822.06 & 72.98 & 71.38 & 70.37 & 6664.45 & 59.06 & 18.03 & 82.74 & 47 \\
\hline & & Cool & 5883.72 & 38.75 & 304.33 & 27.02 & 30.05 & 29.63 & 4619.05 & 40.94 & 3.75 & 17.26 & $3 \approx$ \\
\hline & \multirow[t]{2}{*}{ Summer } & Slightly Cool & 123.98 & 0.82 & 0 & 0.00 & 2.25 & 2.22 & 239.70 & 2.12 & 1.50 & 6.88 & 6. \\
\hline & & Comfortable & 15060.21 & 99.18 & 1126.39 & 100.00 & 99.18 & 97.78 & 11043.81 & 97.88 & 20.28 & 93.12 & 74 \\
\hline & \multirow[t]{2}{*}{ Autumn } & Cool & 15167.67 & 99.89 & 1126.39 & 100.00 & 99.94 & 98.52 & 11210.62 & 99.35 & 21.79 & 100.00 & 81 \\
\hline & & Slightly Cool & 16.53 & 0.11 & 0 & 0.00 & 1.50 & 1.48 & 72.88 & 0.65 & 0 & 0.00 & 0 \\
\hline \multirow[t]{13}{*}{ THI } & \multirow[t]{2}{*}{ Annual } & Cold & 8993.14 & 59.23 & 522.24 & 46.36 & 58.61 & 57.78 & 6868.84 & 60.88 & 17.28 & 79.30 & 41 \\
\hline & & Cool & 6197.06 & 40.77 & 602.64 & 53.64 & 41.32 & 42.22 & 4413.16 & 39.12 & 4.50 & 20.70 & उદ \\
\hline & \multirow[t]{3}{*}{ Winter } & $\begin{array}{l}\text { Excessively } \\
\text { Cold }\end{array}$ & 65.37 & 0.43 & 0 & 0.00 & 0 & 0.00 & 165.31 & 1.47 & 0 & 0.00 & 3. \\
\hline & & Very Cold & 14725.83 & 96.98 & 1091.83 & 96.93 & 96.93 & 95.55 & 10777.05 & 95.51 & 21.79 & 0.00 & $7 \epsilon$ \\
\hline & & Cold & 392.99 & 2.59 & 34.56 & 3.07 & 4.50 & 4.45 & 341.15 & 3.02 & 0 & 0.00 & 0. \\
\hline & Spring & Cold & 14715.31 & 96.91 & 1121.88 & 99.60 & 101.44 & 100.00 & 11206.87 & 99.32 & 21.04 & 96.56 & $7 \stackrel{c}{c}$ \\
\hline & & Cool & 468.89 & 3.09 & 4.50 & 0.40 & 0 & 0.00 & 76.64 & 0.68 & 0.75 & 3.44 & 1. \\
\hline & Summer & Hot & 9335.80 & 61.48 & 736.40 & 65.38 & 63.12 & 62.22 & 6052.04 & 53.64 & 19.53 & 89.63 & $4 \varepsilon$ \\
\hline & & Very Hot & 5724.41 & 37.70 & 386.23 & 34.29 & 36.06 & 35.55 & 4876.79 & 43.22 & 2.25 & 10.37 & $3 c$ \\
\hline & & Sultry & 123.98 & 0.82 & 3.75 & 0.33 & 2.25 & 2.22 & 354.67 & 3.14 & 0 & 0.00 & 2 \\
\hline & Autumn & Cold & 343.40 & 2.26 & 0 & 0.00 & 0 & 0.00 & 564.32 & 5.00 & 0 & 0.00 & 4. \\
\hline & & Cool & 2868.97 & 18.89 & 27.05 & 2.40 & 1.50 & 1.48 & 1859.04 & 16.48 & 5.26 & 24.14 & 6. \\
\hline & & Comfortable & 11971.82 & 78.84 & 1099.34 & 97.60 & 99.94 & 98.52 & 8860.14 & 78.52 & 16.53 & 75.86 & $7 c$ \\
\hline UTCI & Annual & $\begin{array}{l}\text { Slight Cold } \\
\text { Stress }\end{array}$ & 15184.19 & 100.00 & 1126.39 & 100.00 & 101.44 & 100.00 & 11283.51 & 100.00 & 21.79 & 100.00 & 81 \\
\hline & Winter & $\begin{array}{l}\text { Strong Cold } \\
\text { Stress }\end{array}$ & 14.27 & 0.09 & 0 & 0.00 & 0 & 0.00 & 65.37 & 0.58 & 0 & 0.00 & 3. \\
\hline & & $\begin{array}{l}\text { Moderate Cold } \\
\text { Stress }\end{array}$ & 15169.92 & 99.91 & 1126.39 & 100.00 & 101.44 & 100.00 & 11218.14 & 99.42 & 21.79 & 100.00 & 77 \\
\hline & Spring & $\begin{array}{l}\text { Moderate Cold } \\
\text { Stress }\end{array}$ & 832.58 & 5.48 & 0.75 & 0.07 & 0 & 0.00 & 659.00 & 5.84 & 0 & 0.00 & 4. \\
\hline
\end{tabular}




\begin{tabular}{|c|c|c|c|c|c|c|c|c|c|c|c|c|c|}
\hline \multirow{7}{*}{$\begin{array}{l}\text { Bioclimatic } \\
\text { İndices }\end{array}$} & \multirow{4}{*}{$\begin{array}{l}\text { Period } \\
\text { (Season) }\end{array}$} & \multirow{4}{*}{$\begin{array}{l}\begin{array}{l}\text { Bioclimatic } \\
\text { Comfort } \\
\text { Classification }\end{array} \\
\begin{array}{l}\text { Slight Cold } \\
\text { Stress }\end{array}\end{array}$} & \multicolumn{11}{|c|}{ Land Use/Cover Classes } \\
\hline & & & \multirow{2}{*}{\multicolumn{2}{|c|}{$\begin{array}{l}\text { Nat } \\
\text { ural and Semi- } \\
\text { Natural Areas }\end{array}$}} & \multirow{2}{*}{\multicolumn{2}{|c|}{ Forest Areas }} & \multirow{2}{*}{\multicolumn{2}{|c|}{ Water Body }} & \multirow{2}{*}{\multicolumn{2}{|c|}{ Agricultural Areas }} & \multirow{2}{*}{\multicolumn{2}{|c|}{ Artificial Areas }} & \multirow{2}{*}{$\begin{array}{l}U_{I} \\
A_{I}\end{array}$} \\
\hline & & & & & & & & & & & & & \\
\hline & & & 14351.61 & 94.52 & 1125.64 & 99.93 & 101.44 & 100.00 & 10624.51 & 94.16 & 21.79 & 100.00 & $7 \epsilon$ \\
\hline & Summer & $\begin{array}{l}\text { No Thermal } \\
\text { Stress }\end{array}$ & 15184.20 & 100.00 & 1126.39 & 100.00 & 101.44 & 100.00 & 11283.51 & 100.00 & 21.79 & 100.00 & 81 \\
\hline & Autumn & $\begin{array}{l}\text { Slight Cold } \\
\text { Stress }\end{array}$ & 7351.26 & 48.41 & 539.52 & 47.90 & 27.05 & 26.67 & 4629.57 & 41.03 & 6.76 & 31.02 & $1 \varepsilon$ \\
\hline & & $\begin{array}{l}\text { No Thermal } \\
\text { Stress }\end{array}$ & 7832.93 & 51.59 & 586.86 & 52.10 & 74.39 & 73.33 & 6653.93 & 58.97 & 15.02 & 68.98 & 62 \\
\hline
\end{tabular}


Table 8

Spatial distribution of the relationship between bioclimatic comfort classification based on bioclimatic indices and land use/cover - in 2018

\begin{tabular}{|c|c|c|c|c|c|c|c|c|c|c|c|c|c|}
\hline \multirow{3}{*}{$\begin{array}{l}\text { Bioclimatic } \\
\text { İndices }\end{array}$} & \multirow{3}{*}{$\begin{array}{l}\text { Period } \\
\text { (Season) }\end{array}$} & \multirow{3}{*}{$\begin{array}{l}\text { Bioclimatic } \\
\text { Comfort } \\
\text { Classification }\end{array}$} & \multicolumn{11}{|c|}{ Land Use/Cover Classes } \\
\hline & & & \multicolumn{2}{|c|}{$\begin{array}{l}\text { Natural and Semi- } \\
\text { Natural Areas }\end{array}$} & \multicolumn{2}{|c|}{ Forest Areas } & \multicolumn{2}{|c|}{ Water Body } & \multicolumn{2}{|c|}{ Agricultural Areas } & \multicolumn{2}{|c|}{ Artificial Areas } & \multirow{2}{*}{$\begin{array}{l}\mathrm{Ur}_{\mathrm{r}} \\
\mathrm{Al}\end{array}$} \\
\hline & & & $\mathrm{km}^{2}$ & $\%$ & $\mathrm{~km}^{2}$ & $\%$ & $\mathrm{~km}^{2}$ & $\%$ & $\mathrm{~km}^{2}$ & $\%$ & $\mathrm{~km}^{2}$ & $\%$ & \\
\hline \multirow[t]{9}{*}{ ECP } & \multirow[t]{2}{*}{ Annual } & Uncomfortable & 2255.05 & 14.80 & 87.16 & 8.29 & 28.55 & 15.96 & 2911.80 & 26.99 & 24.79 & 30.55 & $3 \varepsilon$ \\
\hline & & Comfortable & 12977.24 & 85.20 & 964.08 & 91.71 & 150.28 & 84.04 & 7875.76 & 73.01 & 56.35 & 69.45 & 91 \\
\hline & Winter & Uncomfortable & 15232.29 & 100.00 & 1051.25 & 100.00 & 178.84 & 100.00 & 10787.57 & 100.00 & 81.15 & 100.00 & 12 \\
\hline & \multirow[t]{2}{*}{ Spring } & Uncomfortable & 320.86 & 2.11 & 0 & 0.00 & 6.01 & 3.36 & 484.67 & 4.49 & 1.50 & 1.85 & 18 \\
\hline & & Comfortable & 14911.43 & 97.89 & 1051.25 & 100.00 & 172.82 & 96.64 & 10302.89 & 95.51 & 79.65 & 98.15 & 11 \\
\hline & \multirow[t]{2}{*}{ Summer } & Uncomfortable & 13153.83 & 86.35 & 980.62 & 93.28 & 145.77 & 81.51 & 8297.32 & 76.92 & 74.39 & 91.67 & 97 \\
\hline & & Comfortable & 2078.46 & 13.65 & 70.63 & 6.72 & 33.06 & 18.49 & 2490.24 & 23.08 & 6.76 & 8.33 & $2 i$ \\
\hline & \multirow[t]{2}{*}{ Autumn } & Uncomfortable & 1570.49 & 10.31 & 12.02 & 1.14 & 19.53 & 10.92 & 1970.25 & 18.26 & 12.77 & 15.74 & 25 \\
\hline & & Comfortable & 13661.80 & 89.69 & 1039.23 & 98.86 & 159.30 & 89.08 & 8817.31 & 81.74 & 68.38 & 84.26 & 9c \\
\hline \multirow[t]{8}{*}{ PET } & \multirow[t]{2}{*}{ Annual } & Cool & 15082.76 & 99.02 & 1051.25 & 100.00 & 178.84 & 100.00 & 10745.49 & 99.61 & 75.14 & 92.59 & 12 \\
\hline & & Slightly Cool & 161.55 & 0.98 & 0 & 0.00 & 0 & 0.00 & 33.81 & 0.39 & 4.50 & 7.41 & 3. \\
\hline & Winter & Very Cold & 15232.29 & 100.00 & 1051.25 & 100.00 & 178.84 & 100.00 & 10787.57 & 100.00 & 81.15 & 100.00 & 12 \\
\hline & Spring & Cool & 15232.29 & 100.00 & 1051.25 & 100.00 & 178.84 & 100.00 & 10787.57 & 100.00 & 81.15 & 100.00 & 12 \\
\hline & \multirow[t]{2}{*}{ Summer } & Comfortable & 11067.10 & 72.66 & 1033.97 & 98.36 & 175.08 & 97.90 & 9605.56 & 89.04 & 69.13 & 85.19 & 11 \\
\hline & & Slightly Warm & 4165.19 & 27.34 & 17.28 & 1.64 & 3.75 & 96.25 & 1182.00 & 10.96 & 12.02 & 14.81 & 9. \\
\hline & \multirow[t]{2}{*}{ Autumn } & Cool & 11931.25 & 78.33 & 1040.73 & 99.00 & 175.83 & 98.32 & 9874.58 & 91.54 & 69.13 & 85.19 & 11 \\
\hline & & Slightly Cool & 3301.04 & 21.67 & 10.52 & 1.00 & 3.75 & 1.68 & 912.99 & 8.46 & 12.02 & 14.81 & 9. \\
\hline \multirow[t]{9}{*}{ THI } & \multirow[t]{2}{*}{ Annual } & Cool & 664.26 & 4.36 & 2.25 & 0.21 & 1.50 & 0.84 & 769.46 & 7.13 & 10.52 & 12.96 & 7. \\
\hline & & Comfortable & 14580.05 & 95.64 & 1046.74 & 99.79 & 178.08 & 99.16 & 10009.83 & 92.87 & 69.13 & 87.04 & 11 \\
\hline & Winter & Cold & 15232.29 & 100.00 & 1051.25 & 100.00 & 178.84 & 100.00 & 10787.57 & 100.00 & 81.15 & 100.00 & 12 \\
\hline & \multirow[t]{2}{*}{ Spring } & Cool & 4117.85 & 27.03 & 48.84 & 4.65 & 28.55 & 15.96 & 3465.60 & 32.13 & 27.05 & 33.33 & $2 \approx$ \\
\hline & & Comfortable & 11114.44 & 72.97 & 1002.41 & 95.35 & 150.28 & 84.04 & 7321.97 & 67.87 & 54.10 & 66.67 & $1 C$ \\
\hline & \multirow[t]{2}{*}{ Summer } & Hot & 325.37 & 2.14 & 0 & 0.00 & 6.76 & 3.78 & 531.26 & 4.92 & 1.50 & 1.85 & 6. \\
\hline & & Very Hot & 14906.92 & 97.86 & 1051.25 & 100.00 & 172.07 & 96.22 & 10256.30 & 95.08 & 79.65 & 98.15 & 11 \\
\hline & Autumn & Cool & 244.96 & 1.61 & 0 & 0.00 & 0.75 & 0.42 & 381.72 & 3.54 & 1.50 & 1.85 & 6. \\
\hline & & Comfortable & 14987.33 & 98.39 & 1051.25 & 100.00 & 178.08 & 99.58 & 10405.84 & 96.46 & 79.65 & 98.15 & 11 \\
\hline UTCI & Annual & $\begin{array}{l}\text { Slight Cold } \\
\text { Stress }\end{array}$ & 7673.63 & 50.38 & 391.49 & 37.24 & 73.64 & 41.18 & 6518.68 & 60.43 & 33.06 & 40.74 & 54 \\
\hline & & $\begin{array}{l}\text { No Thermal } \\
\text { Stress }\end{array}$ & 7570.68 & 49.62 & 657.50 & 62.76 & 105.95 & 58.82 & 4260.62 & 39.57 & 46.58 & 59.26 & $7 C$ \\
\hline & Winter & $\begin{array}{l}\text { Moderate Cold } \\
\text { Stress }\end{array}$ & 14513.92 & 95.28 & 1040.73 & 99.00 & 154.79 & 86.55 & 9622.85 & 89.20 & 56.35 & 69.44 & 85 \\
\hline & & $\begin{array}{l}\text { Slight Cold } \\
\text { Stress }\end{array}$ & 718.36 & 4.72 & 10.52 & 1.00 & 24.04 & 13.45 & 1164.72 & 10.80 & 24.79 & 30.56 & $3 c$ \\
\hline & Spring & $\begin{array}{l}\text { Slight Cold } \\
\text { Stress }\end{array}$ & 11746.39 & 77.12 & 807.03 & 76.77 & 105.20 & 58.82 & 8428.82 & 78.13 & 42.08 & 51.85 & $7 \leftleftarrows$ \\
\hline & & $\begin{array}{l}\text { No Thermal } \\
\text { Stress }\end{array}$ & 3485.89 & 22.88 & 244.21 & 23.23 & 73.64 & 41.18 & 2358.74 & 21.87 & 39.07 & 48.15 & 51 \\
\hline & Summer & $\begin{array}{l}\text { No Thermal } \\
\text { Stress }\end{array}$ & 15232.29 & 100.00 & 1051.25 & 100.00 & 178.84 & 100.00 & 10787.57 & 100.00 & 81.15 & 100.00 & 12 \\
\hline & Autumn & $\begin{array}{l}\text { Slight Cold } \\
\text { Stress }\end{array}$ & 907.73 & 5.96 & 18.78 & 1.79 & 21.79 & 12.18 & 1417.20 & 13.14 & 4.50 & 5.55 & $1 C$ \\
\hline & & $\begin{array}{l}\text { No Thermal } \\
\text { Stress }\end{array}$ & 14324.5 & 94.04 & 1032.46 & 98.21 & 157.04 & 87.82 & 9370.36 & 86.86 & 76.74 & 94.45 & 11 \\
\hline
\end{tabular}


It is thought that the most important factor in this situation is urbanization and wrong land use, as is the case all over the world. As a matter of fact, the rate of urbanization in the province in the last 28 years is $23.01 \%$, as the ratio of urban/built up areas and artificial areas increased by $0.37 \%$ in total. On the other hand, it is among the findings of the study that there is a decrease in agricultural and forest areas. In the study, cold stress conditions are more dominant in the province. However, in the evaluations made according to all parameters and indices, it was revealed that the areas with bioclimatic comfort increased in 28 years, and the density of these areas has shifted from the summer months to the autumn and spring months. It was concluded that the most comfortable areas coincided with the forest and water bodies in both reference years and the parameters/indexes used in the study. This is a proof that the presence of plants and water bodies in cities increases the thermal quality there. When the bioclimatic comfort levels of the urban areas in the relevant reference years were evaluated, it was concluded that the comfortable areas increased in 2018 and their seasonal distributions changed throughout the year. It is possible to say that the climatic comforts of urban areas shift from summer to autumn and spring. By evaluating these data, it is very important to create local strategy plans in urban areas and integrate them into regional plans and policies in order to adapt to climate change studies (Sanchez et al., 2018, Hurlimann et al., 2021).

The most important result of the study that the bioclimatically comfortable areas (location and areal distribution) in the study area and the land use types where these areas overlap differ according to the parameters/indexes used, the relevant years and different periods of the year. It is actually a normal result that bioclimatic comfortable areas consist differently in each index. Because the parameters evaluated in each index and the comfort ranges and comfort groupings of these parameters are defined differently. E.g; Temperature, relative humidity and wind speed parameters were evaluated in the ECP used in the study; the study area was evaluated in 2 scales as "Comfortable" or "Uncomfortable" areas in terms of bioclimatics, according to the environmental parameter ranges. This evaluation is a form of evaluation that limits the interpretation of data. Another index used in the study is the PET index. Relative humidity and wind speed parameters are used in PET, which is the most widely used index in bioclimatic comfort analysis. Daneshvar et al. (2013) emphasize that it is a very important index both in defining the perception of thermal comfort and in analyzing the characteristics of thermal adaptation and comfort intervals. Used in the study and expressed by a simple linear equation that evaluates thermal stress levels, THI provides a reasonable measure of discomfort for various combinations of air temperature and relative humidity conditions (Desai and Dhorde, 2018). The wind speed parameter is not evaluated in the relevant index. UTCI index reflects the effect of various meteorological variables on the heat balance of the human body in a thermo-physiological manner, similar to the PET index. Roshan et al., 2019 emphasize that this index enables the conversion of general meteorological information into an evidence for human biometeorological applications (for example, to evaluate hot stress or cold stress trends). In addition, the comfort ranges in the parameters and indices are also different from each other. For example, the temperature range described as comfortable is $15-20{ }^{\circ} \mathrm{C}, 18-23^{\circ} \mathrm{C}, 9-26^{\circ} \mathrm{C}$ and $15-20{ }^{\circ} \mathrm{C}$ in ECP, PET, UTCl and $\mathrm{THI}$ respectively. The thermal ranges and groups that are described as uncomfortable in parameters and indices are quite different (Table 3-4-5).

The results of the research project by Tahbaz and Beheshti, 2010 confirm the findings of our study. In the related project, Temperature Humidity Index (THI), perceived temperature (PT), Discomfort Index (DI), Tropical Summer Index (TSI), Wet Bulb Globe Temperature (WBGT), physiologically equivalent temperature (PET) and Universal Thermal The Climate Index (UTCI) were investigated and compared in a psychrometric diagram (Tahbaz and Beheshti, 2010). In the related study, it was concluded that these indices were not compatible with each other. For this reason, local observations should be made to discover which index would be more suitable for estimating the thermal conditions of the study area, and it should be clarified with multidisciplinary approaches that show which index would be more accurate to use according to the characteristics/purpose of the project/study. Blazejczyk et al. (2012) emphasize that in terms of microclimatic scale, UTCI better represents the temporal variability of thermal conditions than other indices and reflects even small differences in the intensity of meteorological parameters. The relevant study indicated too that the global nature of UTCI demonstrates the usefulness of this index, with its ability to represent bioclimatic conditions under a wide range of climatic conditions. While Zare et. al (2018) stated that there is a strong relationship between UTCI and PET indices, Cendrowska (2013) revealed that UTCI is more effective in evaluating the bioclimatic conditions of urban areas for tourism and recreation purposes compared to PET index. Farajzadeh et al., (2015) stated that the advantage of the PET index over other indexes is that it is more understandable for people who can evaluate the outdoor thermal situation based on their experience in indoor environments. At this point, it is of great importance to establish urban climate monitoring systems for the evaluation of real bioclimatic conditions in all kinds of local climatic zones of cities. At this point, it is of great importance to establish urban climate monitoring systems for the evaluation of real bioclimatic conditions in all kinds of local climatic zones of cities. Urban climate monitoring systems will be able to allow the identification of the most comfortable areas as well as the most critical areas in terms of thermal stress (hot spots) (Banc et al., 2020).

Many international studies have been carried out on the determination of bioclimatic comfort zones in Turkey in recent years. To determine the bioclimatic comfort conditions of many different cities in Turkey for certain years; Ozyavuz et al (2018), Cetin and Sevik (2020), Erkek et al (2020), Gungor et al (2021), Kilicoglu et al (2021) and Toy et al (2021) have used the PET index; Çetin et al (2019) have relied on PET and DI index methods; while Cetin et al (2018), Adıgüzel et al (2020) and Ozyavuz et al (2018) have adopted the method of ECP parameters. This study is the first study on the bioclimatic comfort areas of Sivas province. The most important fundamental difference of the study from the related studies is that more than one parameter and indices are used in determining the suitable areas in terms of bioclimatic comfort, and therefore it can reveal the differences in approach between the indices. The second important difference is that the bioclimatically comfortable zones change annually and seasonally (in 5 different periods) in 2 different 28 -year time periods (1990 and 2018) according to each parameter/index. The third important difference is that the climatically comfortable zones in the reference years and the land cover of the province are evaluated together.

As a result, this study is a base study for the planning of sustainable urban models that are more compatible with the environment, people and nature in this study, which examines the relationship between the annual and seasonal changes of the bioclimatic comfort zones of Sivas province in 1990 and 2018 with land use.

\section{Declarations}


Acknowledgements: We greatly acknowledge the Turkish State Meteorological Service (TSMS) For providing data for this work.

Author contributions: All authors developed to conception, idea, and design of the study. Material preparation, data collection and analysis, mapping and discussion of all results were performed by all authors. In addition, the frst draft of the manuscript was written and prepared by the authors.

Data availability Data are available upon request on the corresponding author.

Code availability Not applicable.

Ethical approval Not applicable.

Consent to participate Not applicable.

Consent to publish Not applicable.

Conflict of interest The authors declare no competing interests.

\section{References}

1. Adiguzel F, Cetin M, Kaya E, Simsek M, Gungor S, Sert EB (2020) Defining suitable areas for bioclimatic comfort for landscape planning and landscape management in Hatay, Turkey. Theoretical Applied Climatology139(3):1493-1503

2. Ahmadi H, Ahmadi F (2017) Mapping thermal comfort in Iran based on geostatistical methods and bioclimatic indices. Arab J Geosci 10(15):1-12

3. Banc Ș, Croitoru AE, David NA, Scripcă AS (2020) Changes detected in five bioclimatic indices in large Romanian cities over the period $1961-2016$. Atmosphere 11(8):819

4. Blazejczyk K (1994) New climatological-and-physiological model of the human heat balance outdoor (MENEX) and its applications in bioclimatological studies in different scales. Zeszyty Instytutu Geografii i Przestrzennego Zagospodarowania PAN 28:27-58

5. Blazejczyk K, Epstein Y, Jendritzky G, Staiger H, Tinz B (2012) Comparison of UTCl to selected thermal indices. Int J Biometeorol 56(3):515-535

6. Błażejczyk K, Jendritzky G, Bröde P, Fiala D, Havenith G, Epstein Y, Psikuta A, Kampmann B (2013) An introduction to the Universal Thermal Climate Index (UTCI). Geogr Pol 86:5-10

7. Błazejczyk K (2017) BioKlima - Universal Tool for Bioclimatic and Thermophysiological Studies. https://www.igipz.pan.pl/Bioklima-zgik.html (Accessed 5 April 2021)

8. Cendrowska KL (2013) Assessment of bioclimatic conditions in cities for tourism and recreational purposes (A Warsaw case study). Geographia Polonica 86:55-66

9. Cetin M, Topay M, Kaya LG, Yilmaz B (2010) Efficiency of bioclimatic comfort in landscape planning process: The case of Kutahya. Suleyman Demirel University. Journal of Faculty of Forestry A(1):83-95

10. Cetin M (2015) Determining the bioclimatic comfort in Kastamonu City. Environ Monit Assess 187(10):1-10

11. Cetin M, Adiguzel F, Kaya O, Sahap (2018) Mapping of bioclimatic comfort for potential planning using GIS in Aydin.Environment. Development Sustainability 20(1):361-375

12. Cetin M, Adiguzel F, Gungor S, Kaya E, Sancar MC (2019) Evaluation of thermal climatic region areas in terms of building density in urban management and planning for Burdur, Turkey. Air Qual Atmos Health 12(9): 1103-1112. https://doi.org/10.1007 /s11869-019-00727-3

13. Cetin IZ, Sevik H (2020) Investigation of the relationship between bioclimatic comfort and land use by using GIS and RS techniques in Trabzon. Environ Monit Assess 192(2):1-14

14. CORINE (2021) Land use data of Sivas province 1990-2018. Access address: https://land.copernicus.eu/pan-european/corine-land-cover

15. Daneshvar MRM, Bagherzadeh A, Tavousi T (2013) Assessment of bioclimatic comfort conditions based on Physiologically Equivalent Temperature (PET) using the RayMan Model in Iran. Central European Journal of Geosciences 5(1):53-60

16. Desai MS, Dhorde AG (2018) Trends in thermal discomfort indices over western coastal cities of India. Theoretical applied climatology 131(3):1305-1321

17. Dönmez Y, Özyavuz M, Çabuk S, Çorbaci ÖL (2018) Determination of Bioclimatic Comfort Zones by Geographic Information Systems: Karabük Province, Turkey. Journal of International Environmental Application Science 13(1):41-49

18. Emmanuel R (2005) Thermal comfort implications of urbanization in a warm-humid city: the Colombo Metropolitan Region (CMR), Sri Lanka. Build Environ 40(12):1591-1601

19. Erkek E, Başaran N, Atun R, Kalaycı Ö, Lamba H, Öner A, ...Ağaçsapan B (2020) Investigation of the Relationship Between Bioclimatic Comfort and Landuse By Using GIS and RS Techniques: A Case Study of Izmir. Afyon Kocatepe University Journal of Science Engineering 20(1):174-188 (In Turkish)

20. Farajzadeh H, Saligheh M, Alijani B, Matzarakis A (2015) Comparison of selected thermal indices in the northwest of Iran. Natural Environment Change $1: 61-80$

21. Gulyás Á, Unger J, Matzarakis A (2006) Assessment of the microclimatic and human comfort conditions in a complex urban environment: modelling and measurements. Build Environ 41:1713-1722

22. Güçlü Y (2008) Climatic Conditions of Alanya-Samandag Coastal Zone With Respect to Human Comfort and Maritime Tourism Season. Turkish Journal of Geography 50:1-20 (In Turkish) 
23. Gungor S, Cetin M, Adiguzel F (2021) Calculation of comfortable thermal conditions for Mersin urban city planning in Turkey. Air Quality Atmosphere Health 14(4):515-522

24. Hurlimann A, Moosavi S, Browne GR (2021) Urban planning policy must do more to integrate climate change adaptation and mitigation actions. Land Use Policy 101:105188

25. Ichim P, Sfîcă L (2020) The Influence of Urban Climate on Bioclimatic Conditions in the City of lași, Romania. Sustainability 12(22):9652

26. Insaf TZ, Lin S, Sheridan SC (2013) Climate trends in indices for temperature and precipitation across New York State, 1948-2008. Air Qual Atmos Health 6(1):247-257

27. Intergovernmental Panel on Climate Change (IPCC) (2014) Climate change 2014, impacts, adaptation and vulnerability -Summary for policymakers. in: Working Groupll - Contribution to the Fifth Assessment Report of the IPCC

28. Ionac N, Mihoc AC, Tăbleţ P (2012) The bioclimatic comfort of an it office and its occupants' perception about their working environment. Present Environment Sustainable Development 2:81-92

29. Jendritzky G, De Dear R, Havenith G (2012) UTCl - why another thermal index? Int J Biometeorol 56-3:421-428

30. Kantor N, Unger J (2010) Benefits and opportunities of adopting GIS in thermal comfort studies in resting places: An urban park as an example. Landscape Urban Planning 98:36-46

31. Karakounos I, Dimoudi A, Zoras S (2018) The influence of bioclimatic urban redevelopment on outdoor thermal comfort. Energy Build 158:1266-1274

32. Kilicoglu C, Cetin M, Aricak B, Sevik H (2021) Integrating multicriteria decision-making analysis for a GIS-based settlement area in the district of Atakum, Samsun, Turkey. Theoret Appl Climatol 143(1):379-388

33. Kim HS, Chung YS, Cho JH (2017) Long-term variations of dust storms and associated dustfall and related climate factors in Korea during 1997 2016. Air Qual Atmos Health 10(10):1269-1280

34. Mansuroğlu S, Dağ V, Önaç AK (2021) Attitudes of people toward climate change regarding the bioclimatic comfort level in tourism cities; evidence from Antalya, Turkey. Environ Monit Assess 193(7):1-16

35. Matzarakis A, Mayer H, Iziomon MG (1999) Applications of a universal thermal index: physiological equivalent temperature. Int J Biometeorol 43:76-84

36. Matzarakis A, Rutz F, Mayer H (2010) Modelling Radiation fluxes in simple and complex environments - Basics of the Rayman model. Int J Biometeorol $54: 131-139$

37. Olgyay V (2015) Design with climate: bioclimatic approach to architectural regionalism. Princeton University Press, Princeton

38. Ozyavuz M, Aytin BK, Ertin DC (2018) Analysis of Bioclimatic Comfort of Tekirdag (Turkey) Province with Geographical Information Systems. J Environ Prot Ecol 19(1):407-416

39. Roshan G, Almomenin HS, da Silveira Hirashima SQ, Attia S (2019) Estimate of outdoor thermal comfort zones for different climatic regions of Iran. Urban Climate 27:8-23

40. Sánchez FG, Solecki WD, Batalla CR (2018) Climate change adaptation in Europe and the United States: A comparative approach to urban green spaces in Bilbao and New York City. Land Use Policy 79:164-173

41. Sen G, Genc A (2017) The definition of the problems in the forest management certification application process from forester's perspectives in Turkey. J Sustain For 36(4):388-419

42. Svensson MK, Thorsson S, Lindqvist S (2003) A geographical information system model for creating bioclimatic maps-examples from a high, midlatitude city. Int J Biometeorol 47(2):102-112

43. Tahbaz M, Beheshti S (2010) Toward a new chart for outdoor thermal analysis. In Nceub 3rd International Conference: Adapting to Change: New Thinking on Comfort. Cumberland Lodge, Windsor Great Park, UK

44. Thom EC (1959) The discomfort index. Weatherwise 12:57-60

45. Thompson RD, Perry AH (1997) Applied climatology: principles and practice. Psychology Press

46. Topay M, Parladir MO (2015) Suitability analysis for alternative tourism activities with the help of GIS: A case study of Isparta province. Journal of Agricultural Sciences 21(2):300-309

47. Toy S, Yilmaz S, Yilmaz H (2007) Determination of bioclimatic comfort in three different land uses in the city of Erzurum, Turkey. Building environment 42(3):1315-1318

48. Toy S, Çağlak S, Esringü A (2021) Assessment of bioclimatic sensitive spatial planning in a Turkish city, 3 Eskisehir 4. Atmósfera (In Press)

49. TSI (Turkish Statistical Institute) (2021) Population data of Sivas province for the years 1990-2018. Access address:(www.tuik.gov.tr.)

50. TSMS (Turkish State Meteorological Service) (2020) Climate data of Sivas province for the years 1990-2018. ANKARA

51. Vinogradova V (2020) Using the Universal Thermal Climate Index (UTCI) for the assessment of bioclimatic conditions in Russia. International journal of biometeorology: 1-11

52. Willems E, Vandevoort C, Willekens A, Buffaria B (2000) Landscape and land cover diversity index. Access address: http://ec.europa.eu/agriculture/publi/landscape

53. Yılmaz R (2010) Monitoring land use/land cover changes using CORINE land cover data: a case study of Silivri coastal zone in Metropolitan Istanbul. Environ Monit Assess 165(1):603-615

54. Yucedag C, Ozel HB, Cetin M, Sevik H (2019) Variability in morphological traits of seedlings from five Euonymus japonicus cultivars. Environ Monit Assess 191(5):285-284

Page $15 / 22$ 
55. Zare S, Hasheminejad N, Shirvan HE, Hemmatjo R, Sarebanzadeh K, Ahmadi S (2018) Comparing Universal Thermal Climate Index (UTCl) with selected thermal indices/environmental parameters during 12 months of the year. Weather climate extremes 19:49-57

56. Zengin M, Kopar I, Karahan F (2010) Determination of bioclimatic comfort in Erzurum-Rize expressway corridor using GIS. Build Environ 45(1):158-164

\section{Figures}
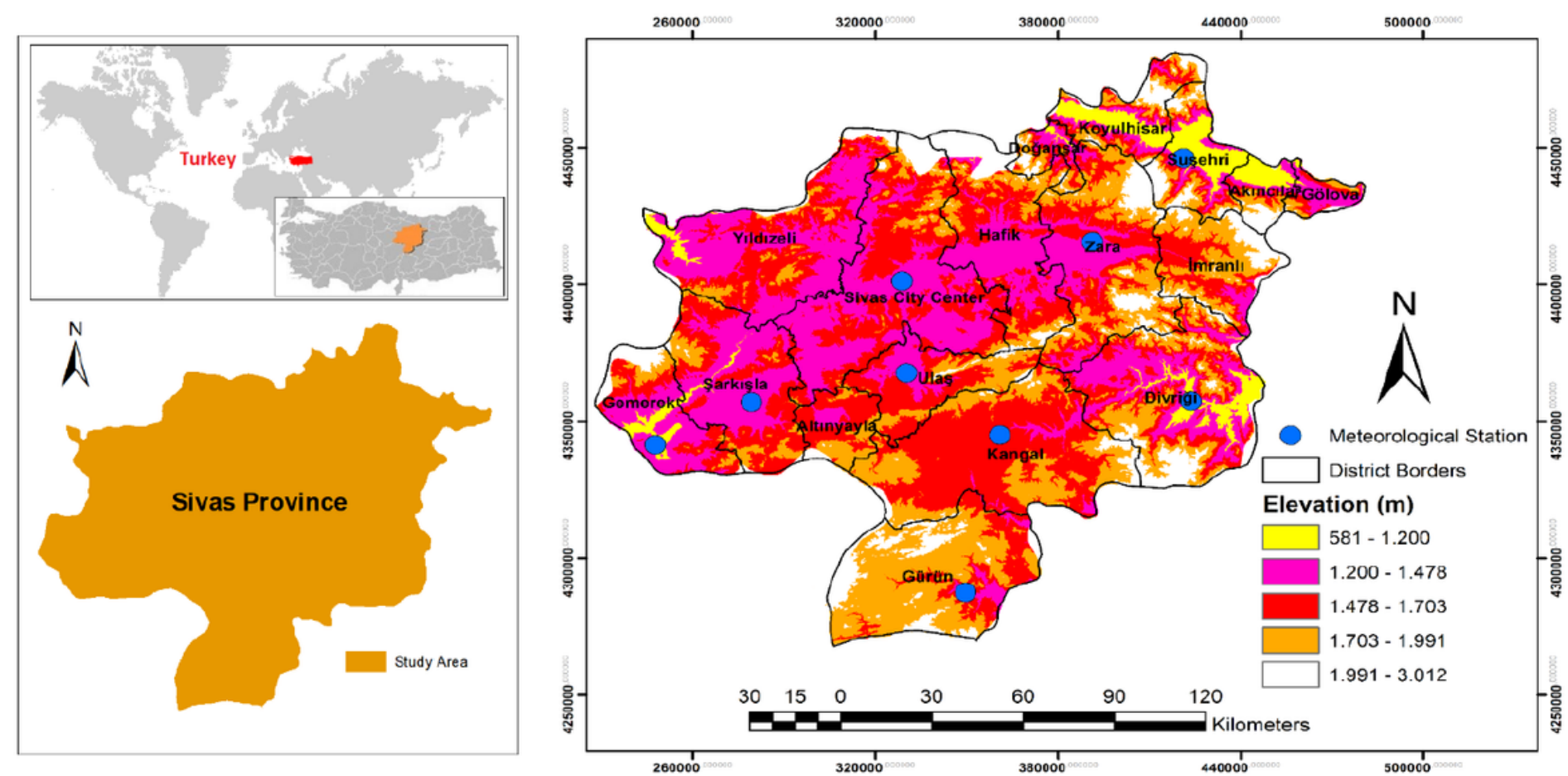

\section{Figure 1}

(a) Location of study area, (b) Spatial distribution of meteorological stations and elevations in the study area 


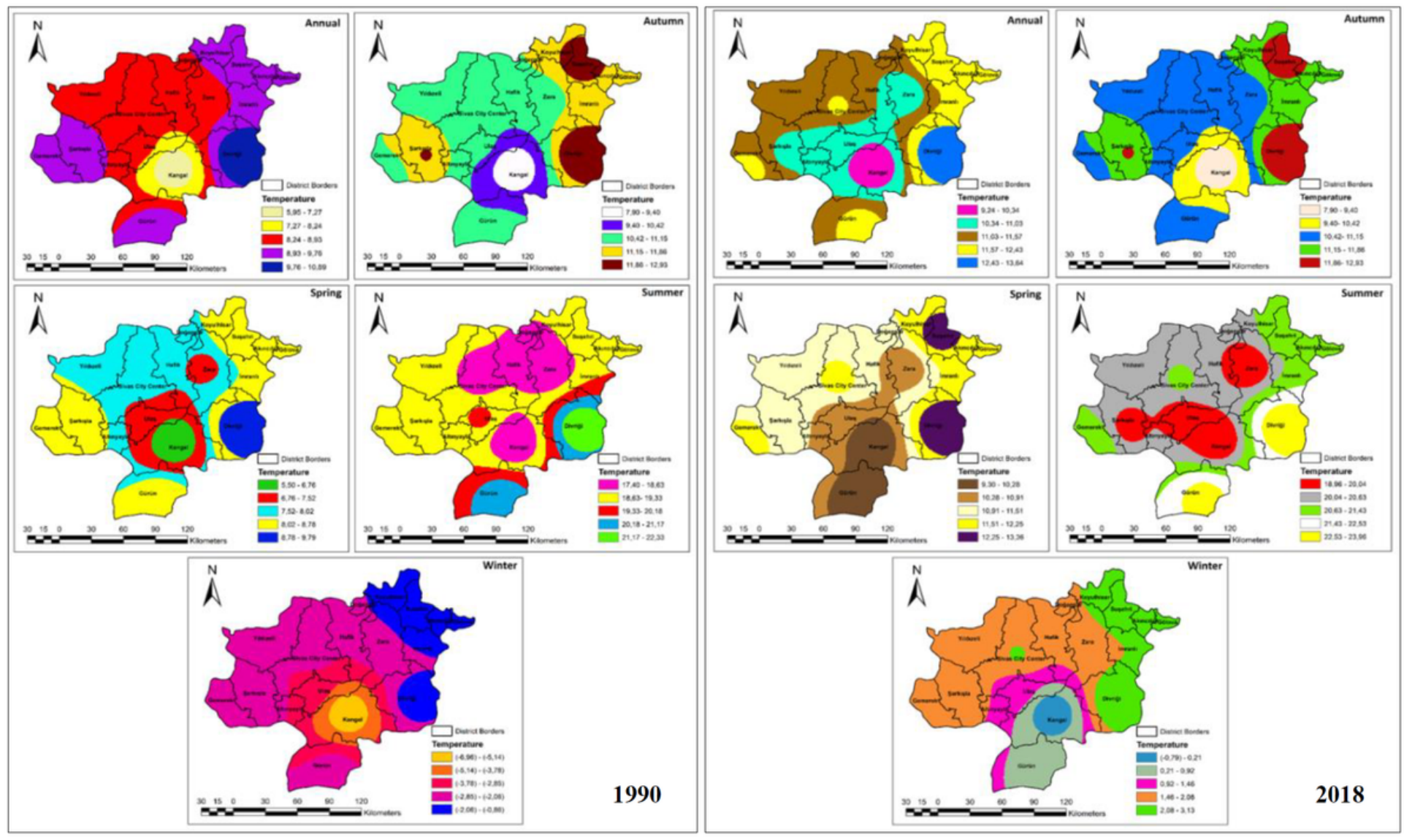

Figure 2

Mapping and spatial distribution of temperature for all periods in 1990 and 2018

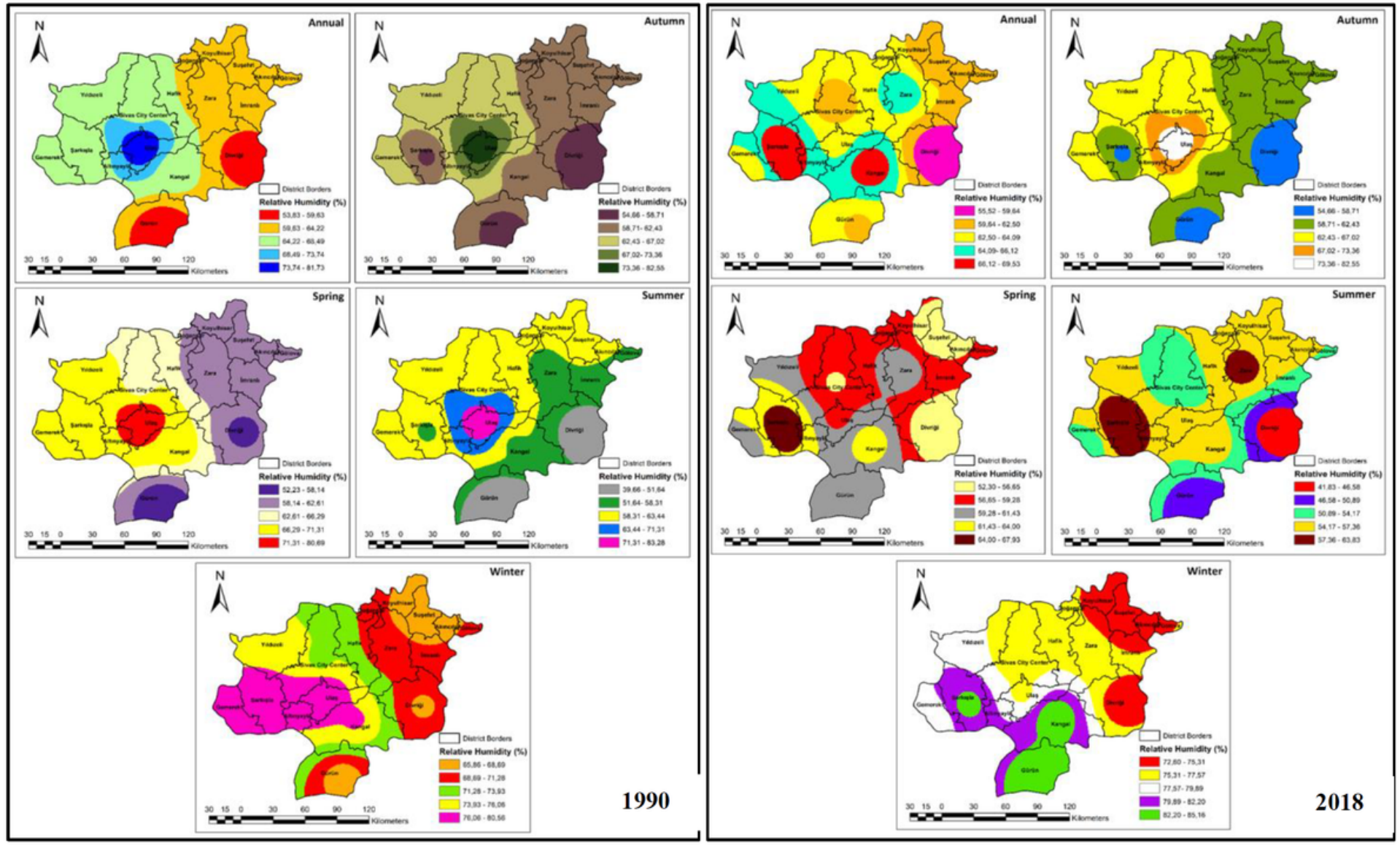


Figure 3

Mapping and spatial distribution of relative humidity for all periods in 1990 and 2018

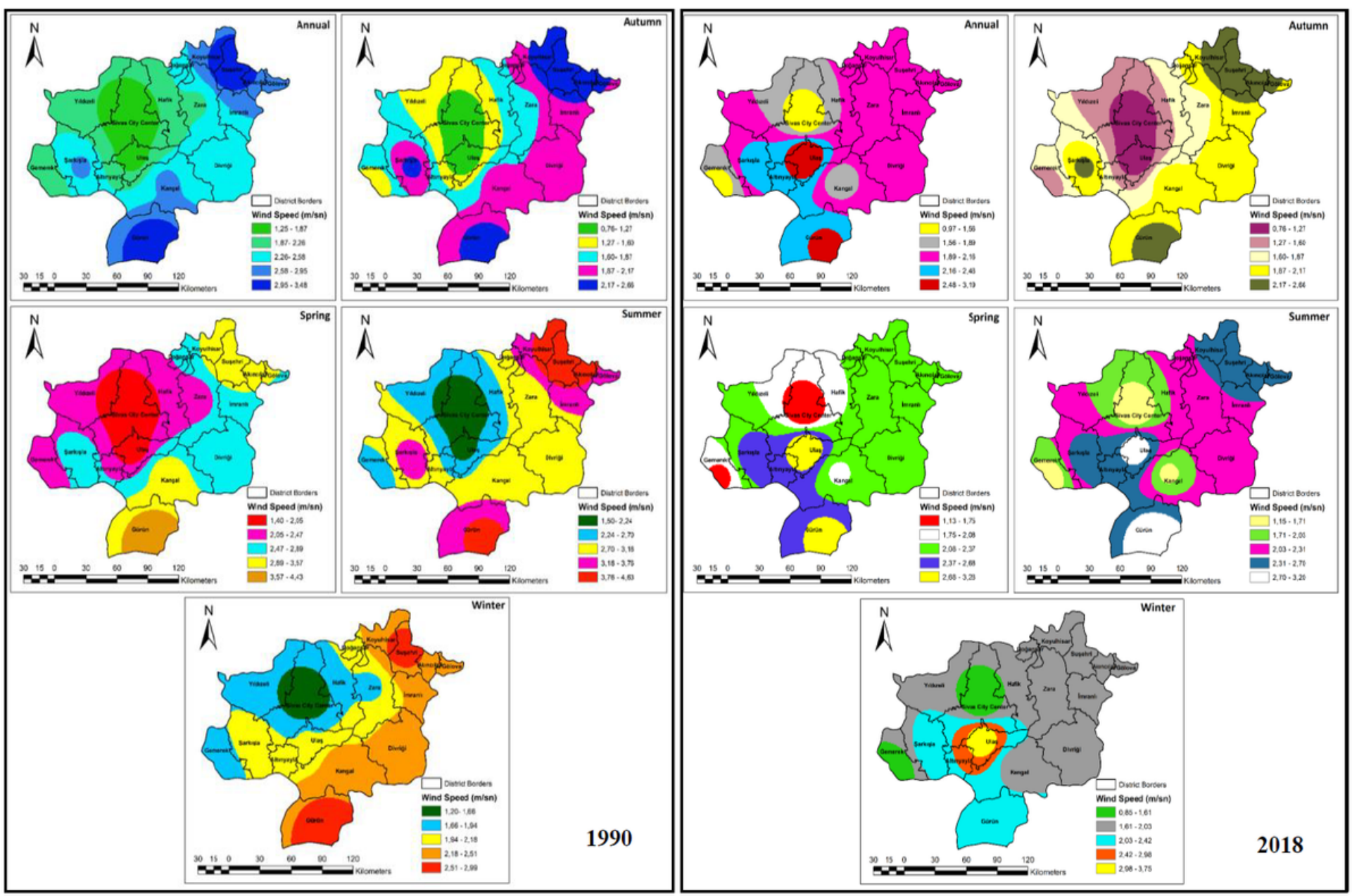

Figure 4

Mapping and spatial distribution of wind speed for all periods in 1990 and 2018 


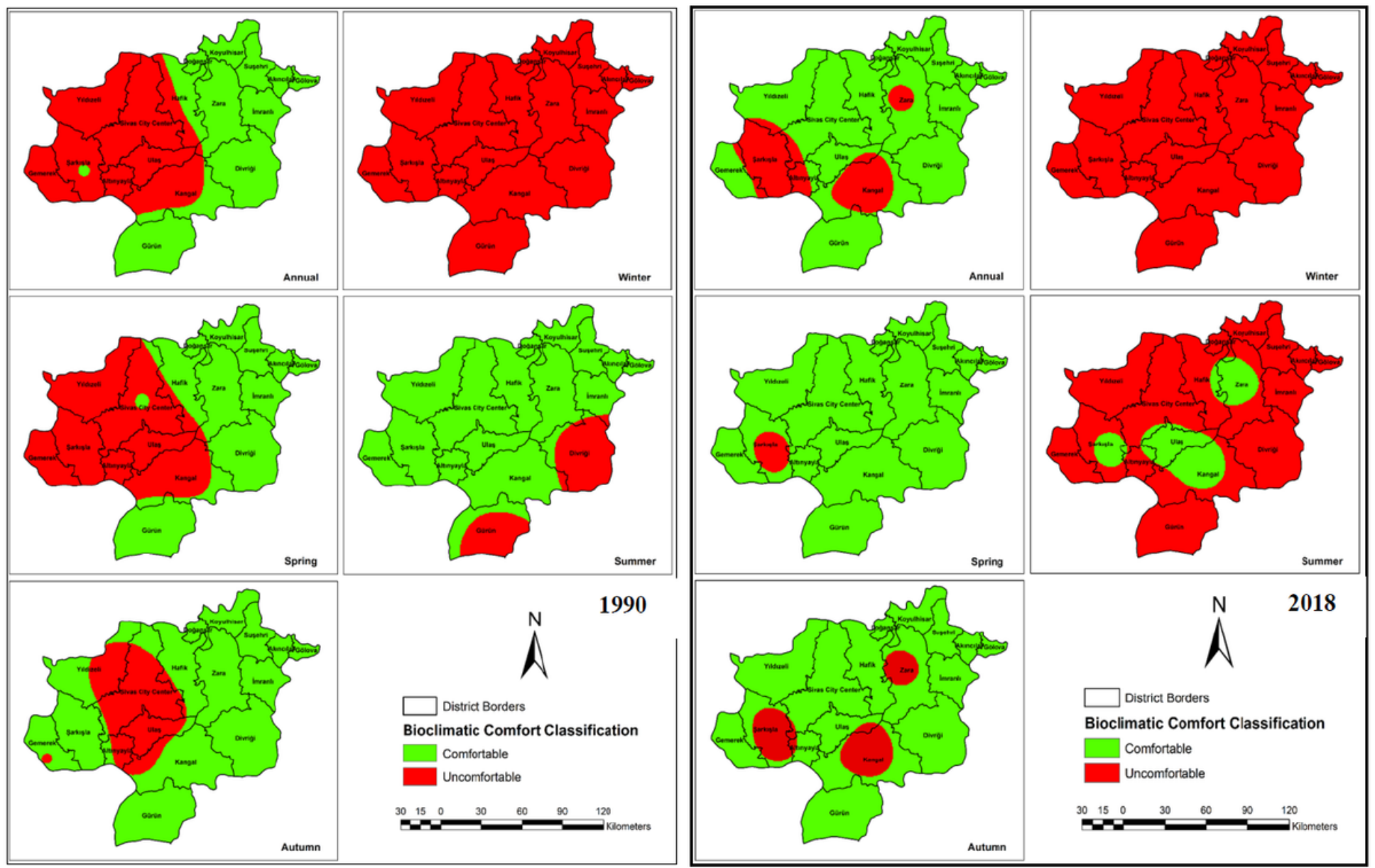

Figure 5

Mapping and spatial distribution of bioclimatic conditions based on environmental climate parameters for all periods in 1990 and 2018 


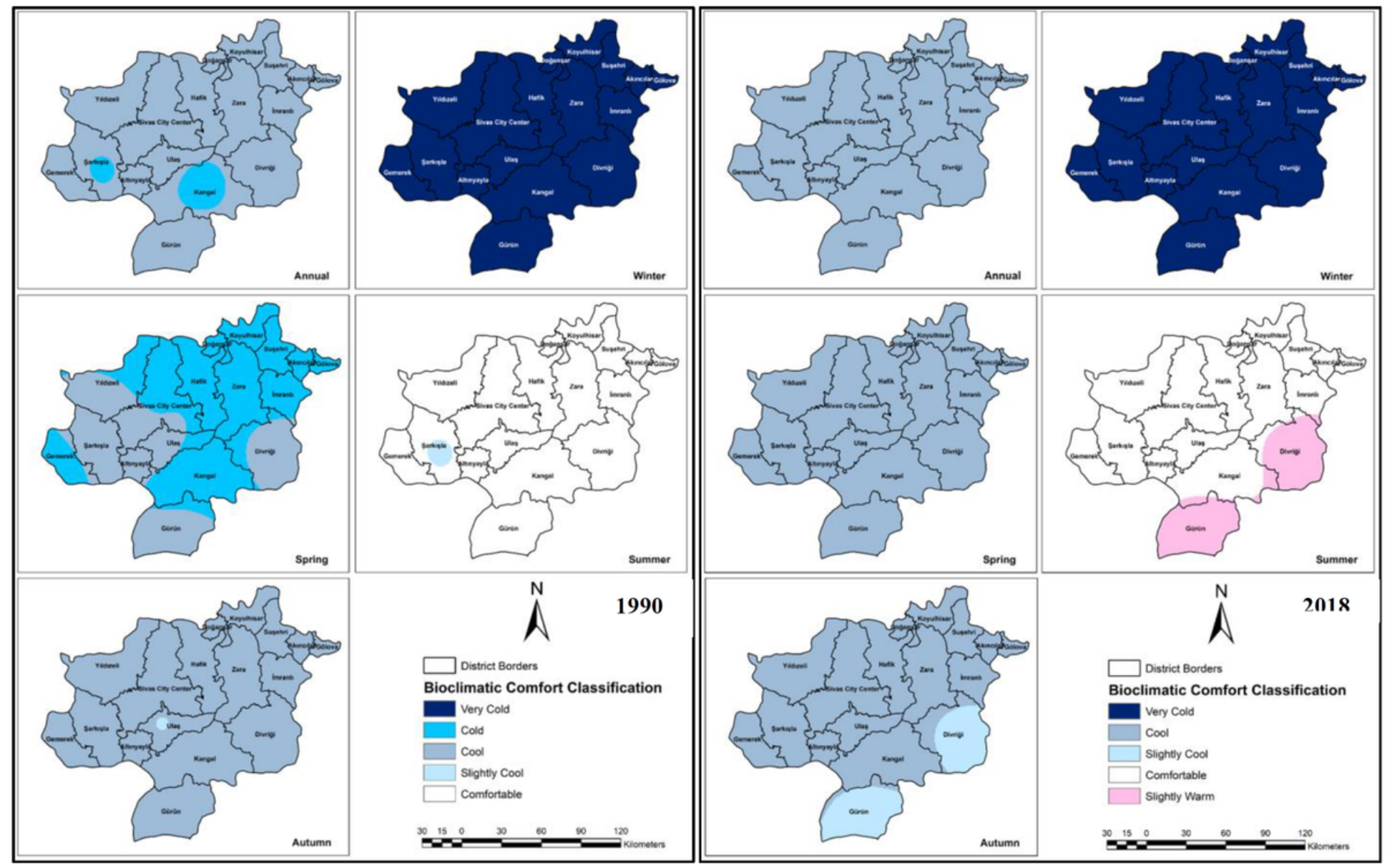

Figure 6

Mapping and spatial distribution of bioclimatic conditions based on PET for all periods in 1990 and 2018 


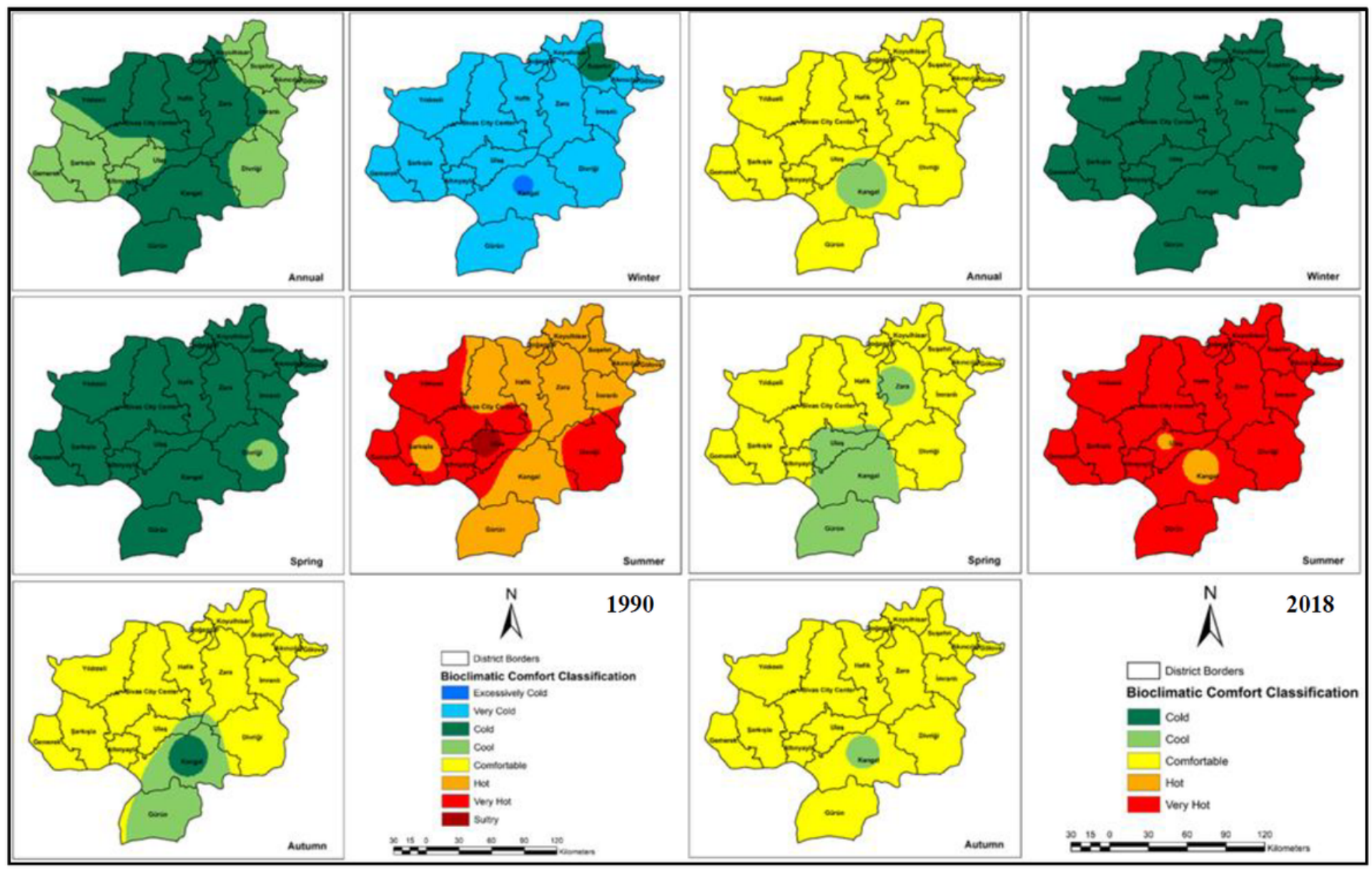

Figure 7

Mapping and spatial distribution of bioclimatic conditions based on THI for all periods in 1990 and 2018 


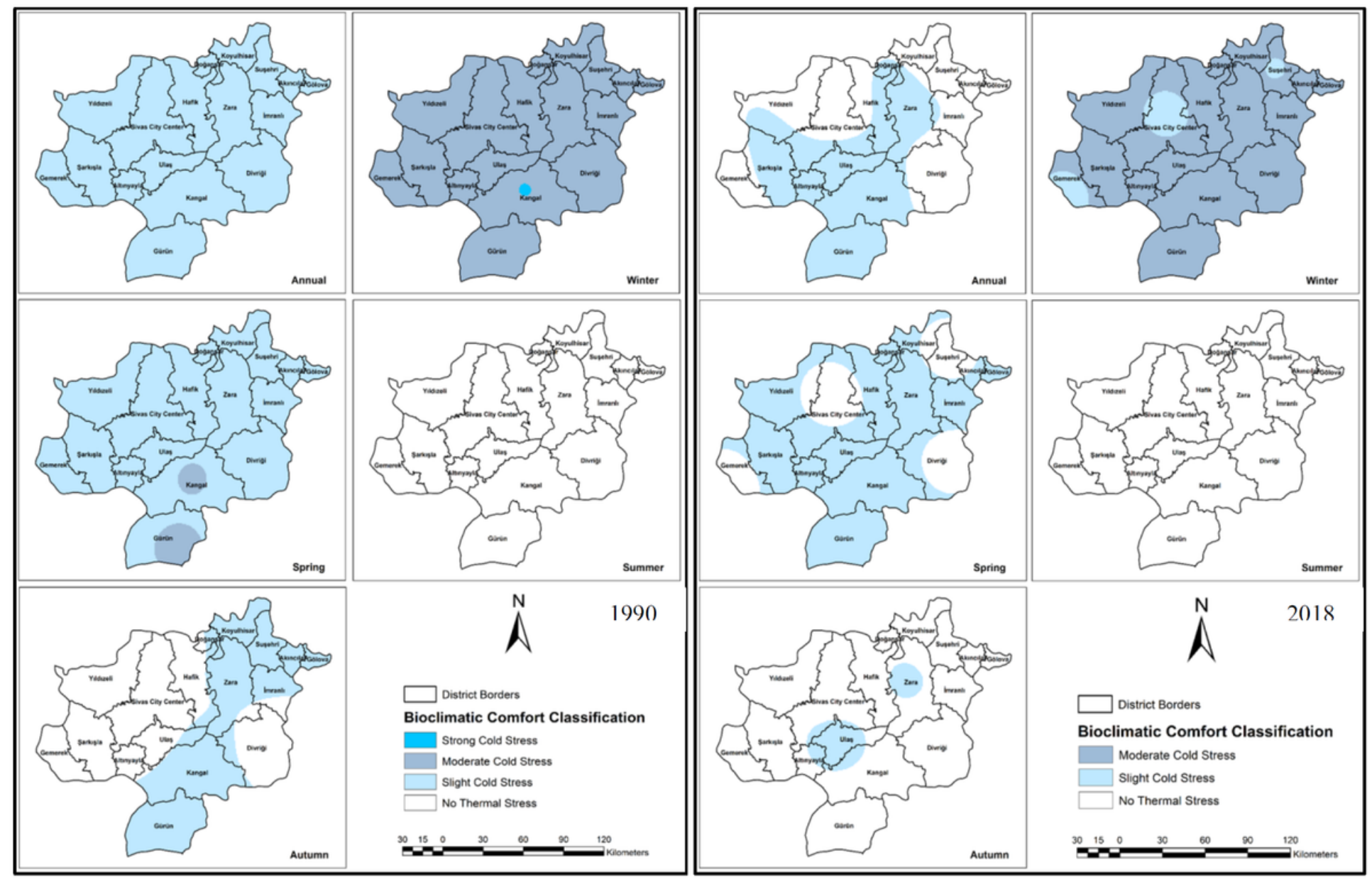

Figure 8

Mapping and spatial distribution of bioclimatic conditions based on UTCI for all periods in 1990 and 2018

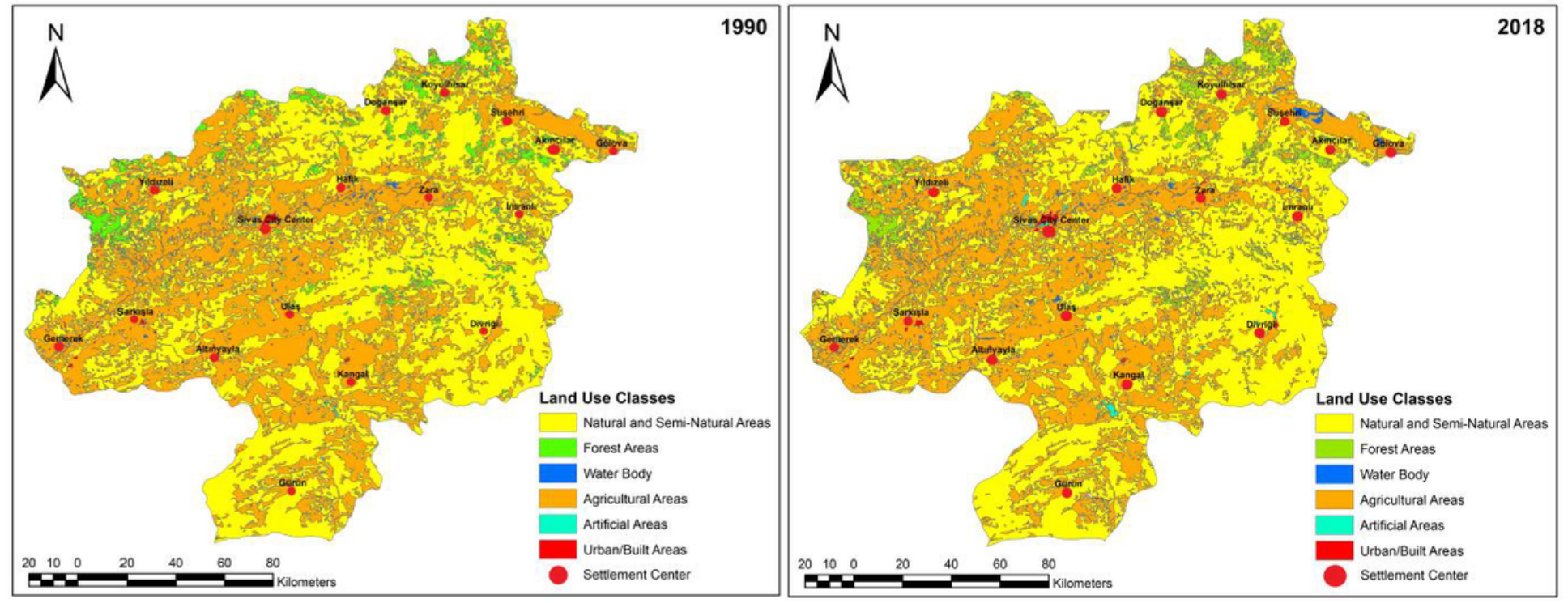

Figure 9

Mapping and spatial distribution of land use/cover based on CORINE in 1990 and 2018 